\title{
Fog composition at Baengnyeong Island in the eastern Yellow Sea: detecting markers of aqueous atmospheric oxidations
}

\author{
A. J. Boris ${ }^{1}$, T. Lee ${ }^{2}$, T. Park ${ }^{2}$, J. Choi ${ }^{3}$, S. J. Seo ${ }^{3}$, and J. L. Collett Jr. ${ }^{1}$ \\ ${ }^{1}$ Department of Atmospheric Science, Colorado State University, Fort Collins, CO, 80521, USA \\ ${ }^{2}$ Department of Environmental Science, Hankuk University of Foreign Studies, Yongin, Republic of Korea \\ ${ }^{3}$ Climate and Air Quality Research Department, National Institute of Environmental Research, Incheon, \\ Republic of Korea
}

Correspondence to: J. L. Collett Jr. (collett@ atmos.colostate.edu)

Received: 14 August 2015 - Published in Atmos. Chem. Phys. Discuss.: 11 September 2015

Revised: 5 December 2015 - Accepted: 9 December 2015 - Published: 19 January 2016

\begin{abstract}
Samples of fog water were collected at Baengnyeong Island (BYI) in the Yellow Sea during the summer of 2014. The most abundant chemical species in the fog water were $\mathrm{NH}_{4}^{+}$(mean of $\left.2220 \mu \mathrm{M}\right), \mathrm{NO}_{3}^{-}(1260 \mu \mathrm{M}), \mathrm{SO}_{4}^{-2}$ $(730 \mu \mathrm{M})$, and $\mathrm{Na}^{+}(551 \mu \mathrm{M})$, with substantial contributions from other species consistent with marine and biomass burning influence on some dates. The $\mathrm{pH}$ of the samples ranged between 3.48 and 5.00, with a mean of 3.94 , intermediate within $\mathrm{pH}$ values of fog/cloud water reported previously in Southeast Asia. Back trajectories $(72 \mathrm{~h}$ ) showed that high relative humidity ( $>80 \%$ ) was encountered upwind of the sampling site by all but one of the sampled air masses, and that the fog composition at BYI can be impacted by several different source regions, including the Sea of Japan, southeastern China, northeastern China, and the East China Sea. Sulfur in the collected fog was highly oxidized: low S(IV) concentrations were measured (mean of $2.36 \mu \mathrm{M}$ ) in contrast to $\mathrm{SO}_{4}^{-2}$ and in contrast to fog/cloud $\mathrm{S}(\mathrm{IV})$ concentrations from pollutant source regions; organosulfate species were also observed and were most likely formed through aging of mainly biogenic volatile organic compounds. Low-molecular-mass organic acids were major contributors to total organic carbon (TOC; 36-69\%), comprising a fraction of TOC at the upper end of that seen in fogs and clouds in other polluted environments. Large contributions were observed from not only acetic and formic acids but also oxalic, succinic, maleic, and other organic acids that can be produced in aqueous atmospheric organic processing (AAOP) reactions. These samples of East Asian fog water containing highly oxidized components represent fog downwind of pollutant sources and
\end{abstract}

can provide new insight into the fate of regional emissions. In particular, these samples demonstrate the result of extensive photochemical aging during multiday transport, including oxidation within wet aerosols and fogs.

\section{Introduction}

The chemistry of the atmosphere occurs within multiple phases, one of which is the aqueous phase. Atmospheric water includes fog droplets, cloud droplets, and wet aerosol particles, all of which can act as miniature aqueous reaction vessels. Distinct chemical phenomena occur within the atmospheric aqueous phase: formation of organic hydrates and protonation/deprotonation occur frequently, time spent by reactants in proximity to one another increases, and interactions involving metals such as the Fenton reactions and iron oxalate complexes are possible (Lelieveld and Crutzen, 1991; Zuo and Hoigné, 1994). The study of carbonaceous species is particularly pertinent to understanding particle-, gas-, and aqueous-phase atmospheric processes because the composition and formation of organics are complex. Particle-phase organics in particular cannot yet be modeled well by laboratory or computer experiments (Aiken et al., 2008; Chen et al., 2015; Heald et al., 2005, 2010) and can account for a large fraction of aerosol mass (Fu et al., 2008; Lin et al., 2014; Liu et al., 2012). Uptake of organic components into atmospheric water represents a pathway for their removal from the atmosphere, via deposition and/or chemical degradation (Collett et al., 2008). Aqueous atmospheric organic 
processing (AAOP) can yield low molecular mass products with typically increased volatilities, effectively reducing pollutant concentrations in an air mass via chemical water treatment (Brinkmann et al., 2003; Zhang et al., 2003). Some reactions of organic material within atmospheric water form aqueous secondary organic aerosol (aqSOA) by oxidation of dissolved organic precursors to form lower-volatility products that remain in the particle phase as fog drops evaporate (Ervens et al., 2011).

The most common approach to studying AAOP reactions in the lab is to introduce ${ }^{\bullet} \mathrm{OH}$ oxidant into a bulk solution of a standard carbonaceous "precursor" molecule such as glyoxal and monitor the reaction as it proceeds (Lim et al., 2010). Some assumptions of this common type of simulation can also be studied within a lab: for example, real cloud water constituents have been shown to cause an effective kinetic slowing, via oxidant competition, of a given organic chemical reaction (Boris et al., 2014). However, while these commonly applied lab simulations are useful for studying specific AAOP reactions, more accurate representations of fogs and clouds are needed to validate simulation results and elucidate more complex phenomena. Daumit et al. (2014) demonstrated that microphysical dynamics of in-droplet diffusion and bidirectional air-water mass transfer are inaccurate in simple "bulk reactions": carrying out a reaction within a photoreactor does not allow species, including oxidants, to continuously partition into and out of solution, as in the real atmosphere (Ervens et al., 2003). Bulk photoreactions also do not correctly simulate differences in chemical constituents between droplets within a cloud (Bator and Collett, 1997; Collett et al., 1994), gradients inside individual droplets (Ervens et al., 2014), or physical processes of fogs and clouds such as evaporation and deposition (Collett et al., 2008; Herckes et al., 2002b; Pandis et al., 1990).

Unequivocal evidence of AAOP reactions within the real atmosphere is challenging to show because no specific molecular or physical tracers for AAOP have been identified. Known products of aqueous oxidation reactions including oxalic acid and $\mathrm{SO}_{4}^{-2}$ are frequently used as non-specific molecular tracers. Successful approaches toward identifying the location and timing of AAOP reactions have included the use of coincident non-specific molecular tracers such as organic acids (Sorooshian et al., 2006, 2013), the predominance of oxalic acid and $\mathrm{SO}_{4}^{-2}$ in a size mode generated from aqueous processes (the droplet size mode, Crahan et al., 2004), and high carbon oxidation states (Chen et al., 2015). Additional observations of AAOP evidence have been summarized by Blando and Turpin (2000) and Ervens et al. (2011). Although oxalic acid in particular has been used as a molecular tracer for AAOP reactions (Sorooshian et al., 2006; Wonaschuetz et al., 2012; Yu et al., 2005), other sources for oxalic acid in the atmosphere have been proposed: gas-phase oxidation of aromatic and anthropogenic molecules (Edney et al., 2000; Kamens et al., 2011; Kleindienst et al., 1999; Borrás and Tortajada-Genaro, 2012;
Kalberer et al., 2000), diesel exhaust emissions (Kawamura and Kaplan, 1987), and forest fire emissions (Narukawa and Kawamura, 1999; Yamasoe et al., 2000).

High aerosol concentrations near major cities in China have been attributed in large part to secondary aerosol formation processes from various sources of carbonaceous emissions (Bian et al., 2014; Zheng et al., 2005). Cloud water collected on Mount Tai in Shandong Province (west of the Yellow Sea) contained some of the highest total organic carbon (TOC) concentrations measured in the world (Herckes et al., 2013; Shen et al., 2012; Wang et al., 2011), consistent with strong regional organic pollutant sources, including agricultural burning (Desyaterik et al., 2013). AAOP reactions could produce measurable quantities of aqSOA and low molecular mass organic acids during atmospheric transport of chemicals, especially at high concentrations and within humid environments as observed in Southeast Asia. Anthropogenic emissions from mainland China and Korea frequently impact remote sites around the Yellow Sea (Kim et al., 2011). Oxygenated organic species observed within atmospheric water and aerosol samples at coastal sites in South Korea (Decesari et al., 2005; Lee et al., 2015) are evidence for AAOP reactions occurring in this part of the world.

Fog water was collected at BYI to characterize the composition of fog formed in aged air masses intercepted in the eastern Yellow Sea. Frequent sea fog events are observed at BYI, particularly during the late spring and early summer (Cho et al., 2000; Zhang et al., 2009). In addition to gathering new information about the composition of fogs in this little-studied region, chemical measurements discussed herein helped to determine whether AAOP reactions occurred at BYI, either within the fog or upwind of the sampling site within cloud droplets/wet aerosol particles. Specifically, it was hypothesized that highly oxidized sulfur and oxidized organics (e.g., low molecular mass organic acids such as oxalic acid) would be measured within the fog water, indicating that AAOP reactions had occurred.

\section{Methods}

\subsection{Study overview}

Fog water was collected from 29 June through 21 July 2014 on BYI at an established atmospheric research center (ARC) run by the Korean National Institute for Environmental Research (NIER; $37^{\circ} 58^{\prime} 0^{\prime \prime} \mathrm{N}, 124^{\circ} 37^{\prime} 4^{\prime \prime} \mathrm{E}$ ). The collection site was approximately $100 \mathrm{~m}$ above sea level (Yoo et al., 2010; Zhang et al., 2009) and was collocated with a meteorological station and an international Interagency Monitoring of Protected Visual Environments (IMPROVE) network site. Meteorological data were accessed online (http://rp5. ru/Weather_archive_on_Baengnyeong_Island). The ARC is on the northwest corner of the island; to the east and south are local agricultural sources of emissions and small towns 
that are home to approximately 4000 total permanent residents. Regular transport of air masses from eastern China and mainland South Korea were expected to provide a high loading of pollutants to the island (Kim et al., 2006), and frequent haze events were indeed encountered during the study. Three-day ( $72 \mathrm{~h}$ ) back trajectories generated using the NOAA HySPLIT model (online version: http://ready.arl. noaa.gov/HYSPLIT.php; $0.5^{\circ}$ global GDAS archived meteorological data) were used to determine the upwind histories of air masses sampled during fog events. The model was initiated using the coordinates of the research station, a height of $100 \mathrm{~m}$, and the approximate beginning time of each fog event. Latitude, longitude, and air mass relative humidity $(\mathrm{RH})$ as estimated by the model were outputted at each $1 \mathrm{~h}$ interval. Periods during which large-scale fires may have impacted fog samples were detected using MODIS archived graphics retrieved from the Naval Research Lab 7 SEAS Data Repository (http://www.nrlmry.navy.mil/aerosol-bin/ 7seas/view_7seas_by_date_t.cgi) and NASA FIRMS (produced by the University of Maryland and provided by NASA FIRMS operated by NASA/GSFC/ESDIS; https://earthdata. nasa.gov/active-fire-data-tab-content-6).

\subsection{Fog collection and handling}

A size-fractionating Caltech Active Strand Cloudwater Collector (sf-CASCC; Demoz et al., 1996) was used to collect small and large fog droplets (diameters predominantly 4-16 and $<16 \mu \mathrm{m}$, respectively). The sf-CASCC is a polycarbonate structure outfitted with a fan at the rear to pull dropletladen air into the body of the collector (at $19 \mathrm{~m}^{3} \mathrm{~min}^{-1}$ ). Droplets were impacted onto rows of forward-tilted Teflon rods and strands and pulled by gravity and aerodynamic drag into Teflon sampling troughs at the bottom of the collector. Fog water was collected for durations of 1 to $3 \mathrm{~h}$; four events (1, 2, 5, and 18 July) were long enough for collection of multiple fog samples. A Gerber Particulate Volume Monitor (PVM-100; Gerber, 1991) was used to determine the liquid water content (LWC) of the atmosphere during the study; an approximate threshold of $30 \mathrm{mg} \mathrm{m}^{-3}$ was used to initiate fog sampling. When fog was not present, the sfCASCC inlet and outlet were covered to prevent collection of contaminants onto the inner surfaces of the collector. The sf-CASCC was cleaned after each fog event: a high-power sprayer was used to rinse deionized water (approx. 2-3 L) through the collector body. Field blanks were collected after each cleaning, and were stored and analyzed in the same manner as samples. Limits of detection (LODs) were calculated using these blanks and are tabulated in Table 1. Deep cleanings were also performed periodically by removing the Teflon strands, rods, and troughs from the body of the sfCASCC and scrubbing all surfaces with Triton X-100 detergent, then thoroughly rinsing all surfaces with deionized water. Collected fog water was refrigerated for a short period of time $(<3 \mathrm{~h})$ prior to separation into aliquots for specific chemical analyses.

Contamination from Triton X-100 detergent in the fog water samples between 14 and 19 July and (seven samples) was discovered by positive ionization HR-ToF-MS analysis. TOC concentrations are not reported for the affected samples; however, duplicate analyses of standards of inorganic ions and organic acids containing Triton X-100 were not different from uncontaminated standards. Peroxides, formaldehyde, and S(IV) were also assumed to be unaffected by the contamination.

Deionized water used in analyses and sample collection at BYI was obtained from a distillation and ion exchangeUV light purification system at the ARC. The calculated charge balance and sample volume were used to determine whether measurements made from a given fog sample were accurate and should be included in results (most samples not containing balanced ionic charges consisted of small liquid volumes). If charge balance, which included all organic and inorganic ionic species, was not within $1.0 \pm 0.3$ (positive/negative charge), that sample was not included (4 of 17 samples were excluded). Directly after sample collection, liquid water from samples with only small collected volumes was dispensed to aliquots according to volume needed and importance of analysis to the study purpose; therefore, in some cases, only some analyses could be carried out for a given sample. For those samples with insufficient volumes $(<2 \mathrm{~mL})$ of the small droplet fraction due to a predominance of large droplets in the sampled fog, the large droplet fraction was assumed to be representative of the entire fog water sample in data analyses. Chemical and physical interactions differ between droplet sizes, and the collection of different sizes of droplets helps preserve real differences in drop composition as compared to bulk fog sampling (Hoag et al., 1999; Moore et al., 2004a, b; Reilly et al., 2001). Mean fog constituent concentrations were calculated from the two droplet fractions (e.g., [(small drop sample volume $\times$ small sample concentration) + (large drop volume $\times$ large drop concentration)]/total sample volume); mean, median, maximum, and minimum values calculated over the size fraction weighted values of all samples were used in further discussion of the fog chemical composition. Air equivalent concentrations (also referred to as loadings) were calculated from molar concentrations in water to establish trends in fog water constituents independent (or less dependent) of the amount of liquid water present during a given fog event. Equation (1) was used, where $i$ represents a given chemical constituent of 
Table 1. Mean, minimum, and maximum concentrations of organic and inorganic species quantified in fog samples collected at BYI. Values below the LOD are shown in italics.

\begin{tabular}{|c|c|c|c|c|c|c|c|c|c|}
\hline \multirow[b]{2}{*}{ Chemical } & \multirow[b]{2}{*}{ Unit } & \multirow{2}{*}{$\begin{array}{r}\text { No. of } \\
\text { samples }\end{array}$} & \multicolumn{3}{|c|}{ Aqueous concentration } & \multirow[b]{2}{*}{ LOD } & \multirow{2}{*}{$\begin{array}{r}\text { Uncertainty } \\
(95 \% \mathrm{CI})\end{array}$} & \multicolumn{2}{|c|}{ Air equivalent concentration } \\
\hline & & & Mean & Min & Max & & & Mean & Unit \\
\hline $\mathrm{pH}$ & - & 11 & 3.94 & 3.48 & 5.00 & - & - & 11.8 & $\mathrm{nmolm}^{-3}$ \\
\hline $\mathrm{NH}_{4}^{+}$ & $\mu \mathrm{M}$ & 13 & 2220 & 253 & 6090 & 7.41 & 4 & 97.8 & $\mathrm{nmol} \mathrm{m}^{-3}$ \\
\hline $\mathrm{NO}_{3}^{-}$ & $\mu \mathrm{M}$ & 13 & 1260 & 185 & 4900 & 0.34 & 10 & 49.0 & $\mathrm{nmolm}^{-3}$ \\
\hline $\mathrm{SO}_{4}^{-2}$ & $\mu \mathrm{M}$ & 13 & 730 & 72.0 & 2270 & 7.16 & 0.4 & 26.6 & $\mathrm{nmolm}^{-3}$ \\
\hline $\mathrm{Na}^{+}$ & $\mu \mathrm{M}$ & 13 & 551 & 24 & 2920 & 2.06 & 2 & 7.55 & $\mathrm{nmolm}^{-3}$ \\
\hline $\mathrm{Cl}^{-}$ & $\mu \mathrm{M}$ & 13 & 253 & 22 & 900 & 0.76 & 3 & 9.29 & $\mathrm{nmolm}^{-3}$ \\
\hline $\mathrm{K}^{+}$ & $\mu \mathrm{M}$ & 13 & 83 & 16 & 172 & 0.70 & 2 & 3.17 & $\mathrm{nmolm}^{-3}$ \\
\hline $\mathrm{Ca}^{+2}$ & $\mu \mathrm{M}$ & 13 & 77 & 12 & 217 & 0.22 & 1 & 3.23 & $\mathrm{nmolm}^{-3}$ \\
\hline $\mathrm{Mg}^{+2}$ & $\mu \mathrm{M}$ & 13 & 73 & 13 & 276 & 0.54 & 1 & 2.53 & $\mathrm{nmolm}^{-3}$ \\
\hline Peroxides & $\mu \mathrm{M}$ & 11 & 7.8 & 0.4 & 58.9 & 0.17 & 0.2 & 0.45 & $\mathrm{nmolm}^{-3}$ \\
\hline S(IV) & $\mu \mathrm{M}$ & 11 & 2.36 & 0.25 & 6.27 & 0.18 & 0.001 & 0.12 & $\mathrm{nmolm}^{-3}$ \\
\hline $\mathrm{NO}_{2}^{-}$ & $\mu \mathrm{M}$ & 13 & 2.1 & 0.3 & 5.6 & 0.05 & 0.9 & 0.18 & $\mathrm{nmolm}^{-3}$ \\
\hline TOC & $\mathrm{mgCL}^{-1}$ & 7 & 17.0 & 4.66 & 24.8 & 0.26 & 0.03 & 413 & $\operatorname{ngC}, \mathrm{m}^{-3}$ \\
\hline Acetate & $\mu \mathrm{M}$ & 11 & 138 & 19.3 & 640 & 2.36 & 0.007 & 4.77 & $\mathrm{nmolm}^{-3}$ \\
\hline Formate & $\mu \mathrm{M}$ & 11 & 120 & 1.77 & 532 & 1.47 & 0.05 & 8.47 & $\mathrm{nmolm}^{-3}$ \\
\hline Oxalate & $\mu \mathrm{M}$ & 11 & 41.5 & 5.86 & 110 & 1.47 & 0.03 & 1.99 & $\mathrm{nmolm}^{-3}$ \\
\hline Succinate & $\mu \mathrm{M}$ & 11 & 22.9 & 3.31 & 52.6 & 0.74 & 0.002 & 1.29 & $\mathrm{nmolm}^{-3}$ \\
\hline Maleate & $\mu \mathrm{M}$ & 11 & 21.1 & 3.04 & 58.8 & 0.29 & 0.02 & 0.72 & $\mathrm{nmolm}^{-3}$ \\
\hline Malonate & $\mu \mathrm{M}$ & 11 & 10.7 & 1.48 & 24.8 & 0.45 & 0.002 & 0.46 & $\mathrm{nmolm}^{-3}$ \\
\hline Pyruvate & $\mu \mathrm{M}$ & 11 & 9.19 & 0.79 & 38.8 & 0.23 & 0.02 & 0.48 & $\mathrm{nmol} \mathrm{m}^{-3}$ \\
\hline Methanesulfonate & $\mu \mathrm{M}$ & 11 & 7.75 & 1.77 & 18.6 & 0.18 & 0.009 & 0.30 & $\mathrm{nmolm}^{-3}$ \\
\hline $\mathrm{HCHO}$ & $\mu \mathrm{M}$ & 10 & 7 & 3 & 21 & 4.81 & 2 & 0.65 & $\mathrm{nmolm}^{-3}$ \\
\hline Glutarate & $\mu \mathrm{M}$ & 11 & 6.5 & 0.92 & 18.3 & 0.66 & 0.02 & 0.30 & $\mathrm{nmol} \mathrm{m}^{-3}$ \\
\hline Valerate & $\mu \mathrm{M}$ & 11 & 1.03 & 0.21 & 3.78 & 0.06 & 0.004 & 0.11 & $\mathrm{nmolm}^{-3}$ \\
\hline Propionate & $\mu \mathrm{M}$ & 11 & 0.88 & 0.35 & 1.36 & 0.06 & 0.004 & 0.11 & $\mathrm{nmolm}^{-3}$ \\
\hline Adipate & $\mu \mathrm{M}$ & 11 & 0.09 & $<$ LOD & 0.24 & 0.006 & 0.04 & 0.01 & $\mathrm{nmolm}^{-3}$ \\
\hline Salicylate & $\mu \mathrm{M}$ & 11 & 0.06 & 0.001 & 0.15 & 0.0003 & 0.04 & 0.006 & $\mathrm{nmolm}^{-3}$ \\
\hline Benzoate & $\mu \mathrm{M}$ & 11 & 0.06 & $<$ LOD & 0.15 & 0.002 & 0.02 & 0.005 & $\mathrm{nmolm}^{-3}$ \\
\hline Pinate & $\mu \mathrm{M}$ & 11 & 0.009 & $<$ LOD & 0.03 & 0.001 & 0.01 & 0.0005 & $\mathrm{nmolm}^{-3}$ \\
\hline Azelate & $\mu \mathrm{M}$ & 11 & 0.02 & $<$ LOD & 0.09 & 0.001 & 0.03 & 0.0009 & $\mathrm{nmolm}^{-3}$ \\
\hline All organic acids & $\mu \mathrm{M}$ & 11 & 379 & 138 & 1000 & - & - & 19.0 & $\mathrm{nmolm}^{-3}$ \\
\hline
\end{tabular}

interest.

$$
\begin{aligned}
& \frac{\mathrm{nmol} i}{\mathrm{~m}^{3} \text { air }}=\frac{\mu \mathrm{mol} i}{\mathrm{~L} \text { sample }} \times \frac{\mathrm{L}}{1000 \mathrm{~mL}} \times \frac{\mathrm{mL}}{1.00 \mathrm{~g}} \\
& \times \text { mass sampled }(\mathrm{g}) \times \frac{\mathrm{hr}}{\mathrm{m}^{3} \text { air }} \times \frac{1}{\text { time sampled }(\mathrm{h})} \\
& \times \frac{1000 \mathrm{nmol} i}{\mu \mathrm{mol} i}
\end{aligned}
$$

The collection rate of the sf-CASCC was assumed to be $19.0 \mathrm{~m}^{3}$ air $\mathrm{min}^{-1}$ (Demoz et al., 1996) and the density of water was assumed to be $1.00 \mathrm{~g} \mathrm{~mL}^{-1}$.

\subsection{Fog water analysis}

Samples were each weighed and divided into aliquots for analyses, and remaining fog water was stored frozen in Nalgene wide-mouth HDPE plastic bottles (also used for col- lection). Measurement of fog water $\mathrm{pH}$ was carried out at the BYI ARC using a Cole-Parmer microelectrode and $\mathrm{pH}$ meter, calibrated with $\mathrm{pH} 4$ and 7 buffers. The mean of three replicate measurements was recorded for each sample. Preservation of other aliquots for chemical analyses (as performed previously; e.g., Benedict et al., 2012) was as follows: peroxides were preserved with para-hydroxyphenylacetic acid (POPHA) and ethylenediaminetetraacetic acid (EDTA), S(IV) was stabilized using formaldehyde and trans-1,2cyclohexylenedinitrilotetraacetic acid (CDTA) and bovine catalase enzyme was added to eliminate hydrogen peroxide, formaldehyde was preserved with $\mathrm{Na}_{2} \mathrm{SO}_{3}$ and CDTA, samples for analysis of major ionic species $\left(\mathrm{Cl}^{-}, \mathrm{NO}_{2}^{-}, \mathrm{NO}_{3}^{-}\right.$, $\mathrm{SO}_{4}^{-2}, \mathrm{Na}^{+}, \mathrm{NH}_{4}^{+}, \mathrm{K}^{+}, \mathrm{Mg}^{+2}, \mathrm{Ca}^{+2}$ ) were aliquoted without added reagents, and microbial activity was eliminated for the storage of organic acids and other organic components by addition of chloroform. Aliquots for TOC and 


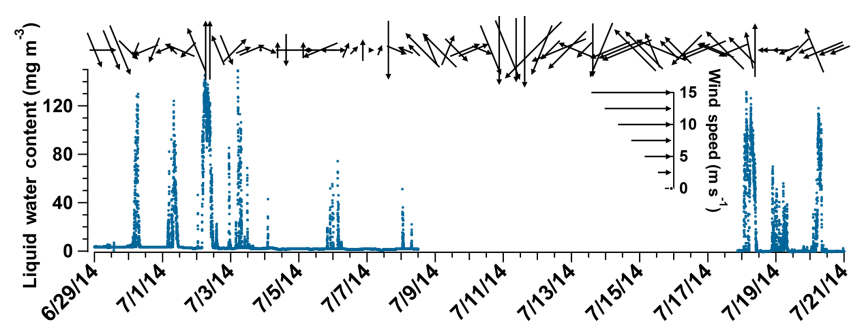

Figure 1. Wind speed and direction during fog sampling period, shown as vector arrows (top): speed is displayed as the length of each arrow and direction is displayed as tilt, pointing away from wind origin. LWC measured during the entire study period is shown in blue along the bottom of the plot. Fog was not collected in midJuly during the monsoonal period.

carbohydrates (including levoglucosan) analysis were taken from thawed samples after arrival at Colorado State University (CSU). Additional organic molecules were identified and/or quantified via high-performance liquid chromatography (HPLC) followed by negative electrospray ionization high-resolution time-of-flight mass spectrometry ((-)-ESIHR-ToF-MS) from the aliquot preserved for organic acids analysis. Levoglucosan and other carbohydrates were measured using high-performance anion exchange chromatography with pulsed amperometric detection (HPAEC-PAD) as described previously (Sullivan et al., 2008) from frozen remaining fog water samples; only some samples were analyzed for carbohydrates.

\section{Results and discussion}

Fog water was collected during nine fog events (17 total samples) at the BYI ARC during July 2014; seven events and 13 samples were included in mean chemical concentrations calculated over the duration of the sampling campaign and will be discussed here (Fig. 1). Events on 2 and 18 July persisted for several hours, allowing collection of up to five samples per event. Air masses sampled during the seven fog events traveled either from the south over the Yellow Sea as documented in Zhang et al. (2009), from the west over eastern China, from the east over the Sea of Japan, or from the north over northeastern China (Fig. 2).

\subsection{Fog characteristics and major contributing species}

A moderately acidic $\mathrm{pH}$ was observed (study mean 3.94, ranging between 3.48 and 5.00). This value is intermediate between values measured in fog and cloud samples from Southeast Asia (Mount Tai: pH 3.68, Wang et al., 2011; Jeju Island, Korea: pH 5.2, Kim et al., 2006; Daekwanreung, Korea: pH 4.7, Kim et al., 2006; and Shanghai, China: pH 5.97, $\mathrm{Li}$ et al., 2011a). Major inorganic species contributing to the measured acidity of the fog water at BYI (Table 1; Fig. 3) were $\mathrm{NH}_{4}^{+}$(mean concentration of $2220 \mu \mathrm{M}$ ), followed by
$\mathrm{NO}_{3}^{-}(1260 \mu \mathrm{M})$ and $\mathrm{SO}_{4}^{-2}(730 \mu \mathrm{M})$; these concentrations were elevated compared to fog and cloud samples collected globally (e.g., Collett et al., 2002; Raja et al., 2008; Wang et al., 2011). Sea salt was also an abundant constituent of the fog water (mean concentrations of $551 \mu \mathrm{M} \mathrm{Na}^{+}$and $253 \mu \mathrm{M}$ $\mathrm{Cl}^{-}$), as was organic matter (mean $276 \mu \mathrm{M}$, estimated using a molecular mass of $100 \mathrm{~g} \mathrm{~mol}^{-1}$ and $\mathrm{OM} / \mathrm{OC}=1.8 \mathrm{Zhang}$ et al., 2005). The mean $\mathrm{NH}_{4}^{+}$concentration measured at BYI was within the upper range of measured $\mathrm{NH}_{4}^{+}$in fog and cloud samples (similar to, for example, the Po Valley, Italy (Fuzzi et al., 1992) and Baton Rouge, Louisiana; Raja et al., 2008). Although agriculture was a main land use on BYI, no correlation between wind direction and fog $\mathrm{NH}_{4}^{+}$concentrations was observed (Fig. SI-1 in the Supplement), suggesting long-range transport of fine particle $\mathrm{NH}_{4}^{+}$as an important source. The concentrations of $\mathrm{Ca}^{+2}$ (mean $77 \mu \mathrm{M}$ ) were within the range of previous studies in other, remote parts of the world (Benedict et al., 2012; Munger et al., 1989), indicating that inputs to fog water chemistry by mineral dust were likely unimportant during the study period (Arimoto et al., 2004; Mattigod et al., 1990; Kawamura et al., 2004).

Concentrations of nearly all species were highest in samples with westerly back trajectories (Fig. 4). Anthropogenic influence was likely greatest from this sector because of the large number of urban areas and major industry in Shandong Province and surrounding regions (Cao et al., 2006). The lowest concentrations of most species originated from the east (note that only one sample included in the analyses originated from the east). The only exceptions were $\mathrm{Na}^{+}$, from the north, and $\mathrm{H}^{+}$, which was least abundant from the west due to the contribution of $\mathrm{NH}_{4}^{+}$to fog acidity.

\subsection{Marine source contribution}

Evidence of a marine contribution to fog composition was clear. Upwind trajectories of all air masses sampled included some duration over the Yellow Sea, and in some cases the Sea of Japan (Fig. 2). Measured $\mathrm{Ca}^{+2}$ was contributed in part by sea salt particle scavenging: $21 \%$ was attributed to sea salt (Fig. SI-2) using an observed ratio in seawater of $0.022 \mathrm{~mol}$ $\mathrm{Ca}^{+2} / \mathrm{mol} \mathrm{Na}^{+}$(Lee, 2007; Radojevic and Bashkin, 2006). Depletion of particle-phase $\mathrm{Cl}^{-}$appears to have occurred in some scavenged sea salt particles, likely due to displacement of $\mathrm{HCl}$ to the gas phase by $\mathrm{NO}_{3}^{-}$and $\mathrm{SO}_{4}^{-2}$ (Mouri and Okada, 1993) or organic acids (Wang et al., 2015). Measured $\mathrm{Cl}^{-} / \mathrm{Na}^{+}$molar ratios ranged as low as 0.08 , with a mean value of 1.20; this mean value is within measurement error (Table 1) of the typical sea salt ratio of 1.16 (Radojevic and Bashkin, 2006). In some samples, the $\mathrm{Cl}^{-}$concentration was in excess of the sea salt ratio, indicating possible contributions from other sources such as incineration or coal combustion (McCulloch et al., 1999). Small contributions of $\mathrm{K}^{+}$(study mean concentration $83 \mu \mathrm{M}$ ) and $\mathrm{SO}_{4}^{-2}$ were estimated to derive from scavenged sea salt particles: only $12 \%$ of the measured $\mathrm{K}^{+}$and $6 \%$ of the $\mathrm{SO}_{4}^{-2}$ were attributed to 


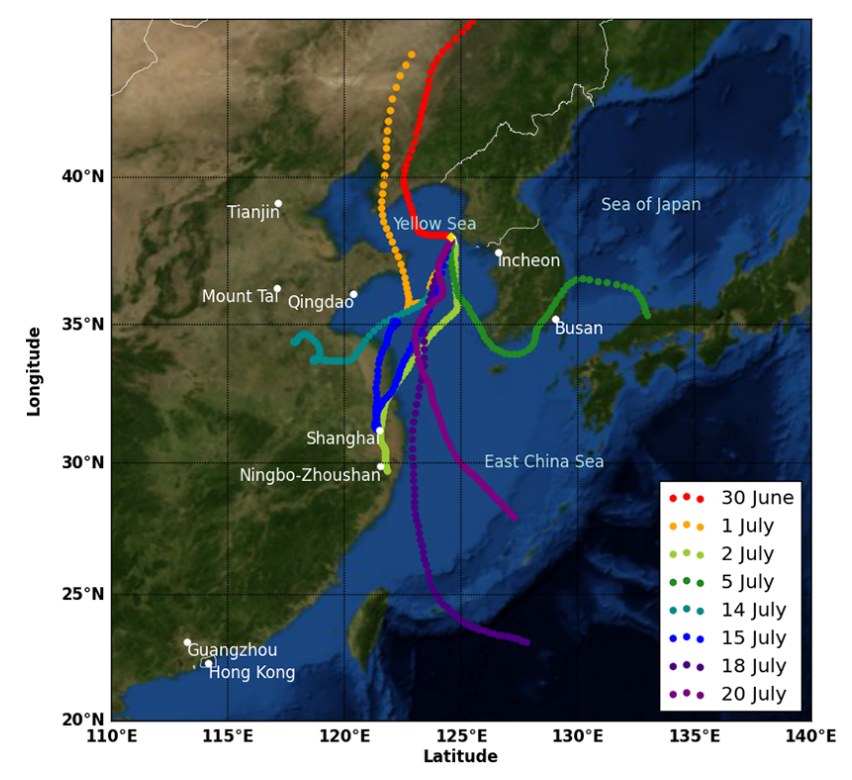

Figure 2. Back trajectories of air masses intercepted during fog events ( $72 \mathrm{~h}$ at $1 \mathrm{~h}$ time resolution; HySPLIT). Locations labeled on plot include Mount Tai, where previous atmospheric water chemical measurements were made, and the highest throughput shipping ports in the region pictured. The BYI ARC is shown as a gold diamond. Sectors were defined to determine whether particular source regions existed for chemical constituents of the fog: northerly (30 June and 1 July), westerly (2, 14, and 15 July), southerly (18 and 20 July), and easterly (5 July). Each trajectory was initiated at the approximate beginning of a fog event. Imagery from NASA Blue Marble; plot generated using Python Matplotlib Toolkit BaseMap.

a marine source on average. This estimate of nss- $\mathrm{SO}_{4}^{-2}$ does not account for $\mathrm{SO}_{4}^{-2}$ formed via oxidation of biogenic, marine dimethyl sulfide, which could be as much as $12 \%$ (Yang et al., 2009). Elevated concentrations of cations including $\mathrm{K}^{+}$ in aerosol have also been associated with the influence of biomass burning activities (Andreae, 1983; Lee et al., 2010), mineral dust from arid regions (Zhang et al., 1993), and/or construction in urban areas (Li et al., 2011b).

\subsection{Inorganic sulfur}

Aqueous sulfur oxidation in the $\mathrm{pH}$ range measured in this study (3.48-5.00) is expected to be dominated by reaction with $\mathrm{H}_{2} \mathrm{O}_{2}$ (Rao and Collett, 1995). The mean concentrations of total peroxides and S(IV) (7.8 and $2.36 \mu \mathrm{M}$, respectively; Table 1) were low compared to the mean S(IV) and peroxides concentrations measured during summer 2007 and 2008 field campaigns at Mount Tai, China (Shen et al., 2012), consistent with a low potential for additional S(IV) oxidation within the BYI fog samples (Fig. 5). Since Mount Tai is located west across the Yellow Sea from BYI and is influenced by the abundant $\mathrm{SO}_{2}$ sources in Shandong Province, including large numbers of coal-fired power plants, these observations are consistent with extensive aging of S(IV) during transport to

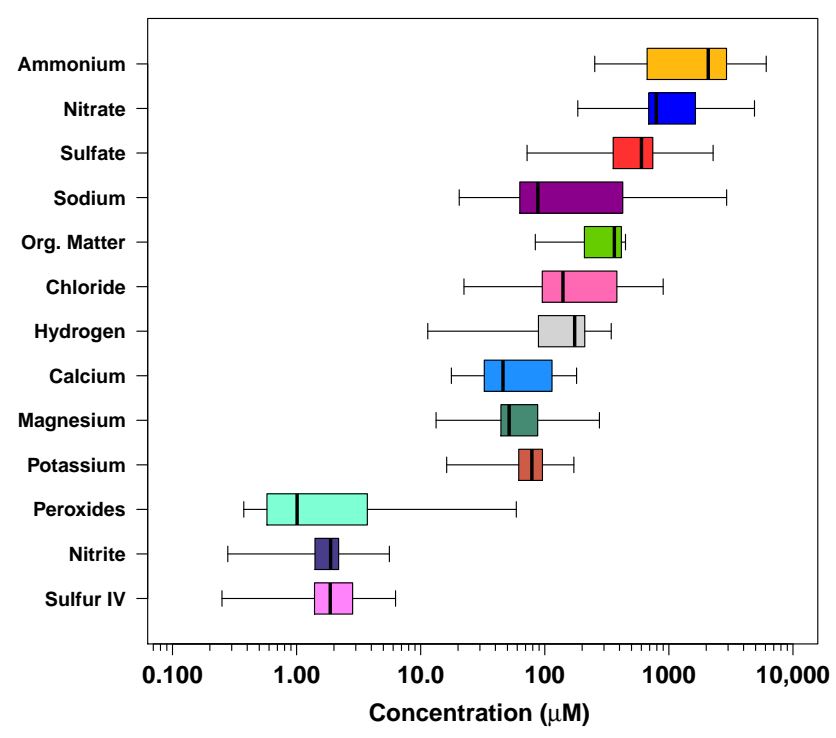

Figure 3. Concentrations of major components quantified in BYI fog samples. Boxes show 25th and 75th percentiles with the median bar in the center, and whiskers show outliers. Total organic matter was calculated from measured TOC using a ratio of $1.8 \mathrm{~g} / 1.0 \mathrm{~g}$ OM/OC (Zhang et al., 2005) and an estimated mean molecular mass of $100 \mathrm{~g} \mathrm{~mol}^{-1}$. Note that for most ions, $n=13$; for $\mathrm{pH}, \mathrm{S}(\mathrm{IV})$, and peroxides, $n=11$; for formaldehyde, $n=10$; and for total organic matter, $n=7$.

the BYI fog collection site. In contrast to BYI measurements, cloud samples from remote areas contain high concentrations of peroxides and low concentrations of S(IV) $(1.9-610 \mu \mathrm{M}$ peroxides, <0.91-3.7 $\mu \mathrm{M} \mathrm{S}(\mathrm{IV})$; Straub et al., 2007; Benedict et al., 2012). Measured $\mathrm{SO}_{4}^{-2}$ was abundant within BYI samples, demonstrating that sources of atmospheric sulfur existed upwind, and that oxidation of sulfur occurred prior to arrival at BYI. Between 98.9 and $99.8 \%$ of sulfur measured (as the sum of $\mathrm{SO}_{4}^{-2}$ and $\mathrm{S}(\mathrm{IV})$ ) was in the form of $\mathrm{SO}_{4}^{-2}$. International shipping lanes could also contribute to the measured $\mathrm{SO}_{4}^{-2}$ concentrations in BYI fog: some of the world's largest shipping ports are located in the Yellow Sea (Streets et al., 2000). The contribution of fine particle $(<1 \mu \mathrm{m}$ diameter) $\mathrm{SO}_{4}^{-2}$ has been estimated at $\leq 15 \%$ from ship oil combustion in this region (Lauer et al., 2007), and shipping routes in the Yellow Sea have been identified as major $\mathrm{SO}_{2}$ source regions (Kang et al., 2006). Shipping emissions have also been associated with elevated concentrations of other atmospheric constituents, including $\mathrm{NO}_{3}^{-}$(Prabhakar et al., 2014). Methanesulfonic acid (MSA) was also observed within all fog samples collected at BYI, indicating that oxidation of marine emissions via either ${ }^{\bullet} \mathrm{OH}$ or ${ }^{\bullet} \mathrm{NO}_{3}$ reaction occurred upwind of fog collection at BYI (Seinfeld and Pandis, 2006; Kukui et al., 2003; Scaduto, 1995). 

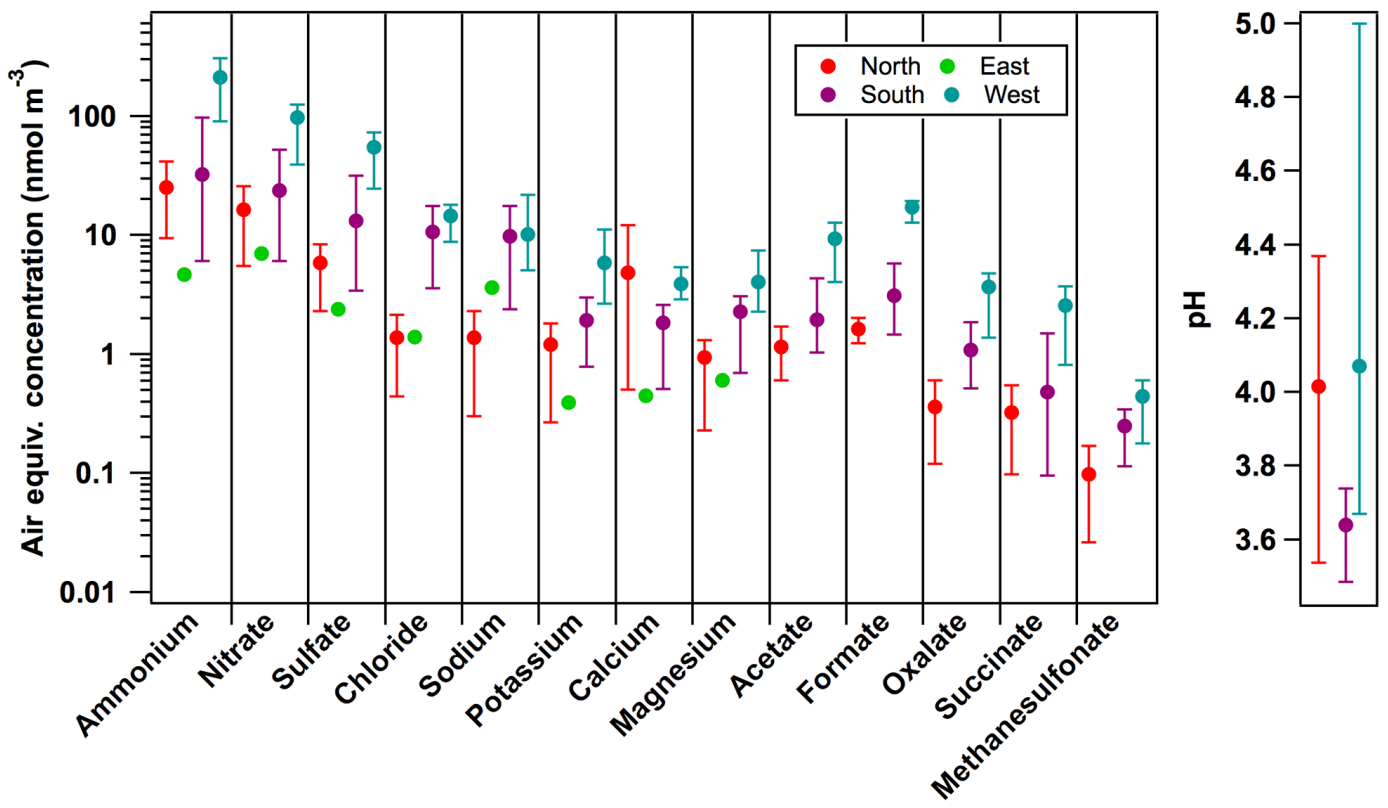

Figure 4. Sector analysis of most abundant inorganic fog water components, as well as selected organic acids. Highest concentrations of most species originated from the west. For $\mathrm{Na}^{+}$and $\mathrm{Cl}^{-}$, high concentrations were also observed from the south. $\mathrm{Ca}^{+2}$ concentrations were also heightened within samples with northerly trajectories, which may suggest a continental dust source. In agreement with high measured $\mathrm{NH}_{4}^{+}$concentrations, $\mathrm{pH}$ was highest from the west. Note that samples were low in volume in some cases so that $\mathrm{pH}$ analyses were not performed. For inorganic species except $\mathrm{pH}, n=1$ easterly, $n=3$ northerly, $n=4$ southerly, and $n=5$ for westerly trajectories. For organic species and $\mathrm{pH}, n=0$ easterly, $n=2$ northerly, $n=3$ southerly, and $n=4$ westerly.

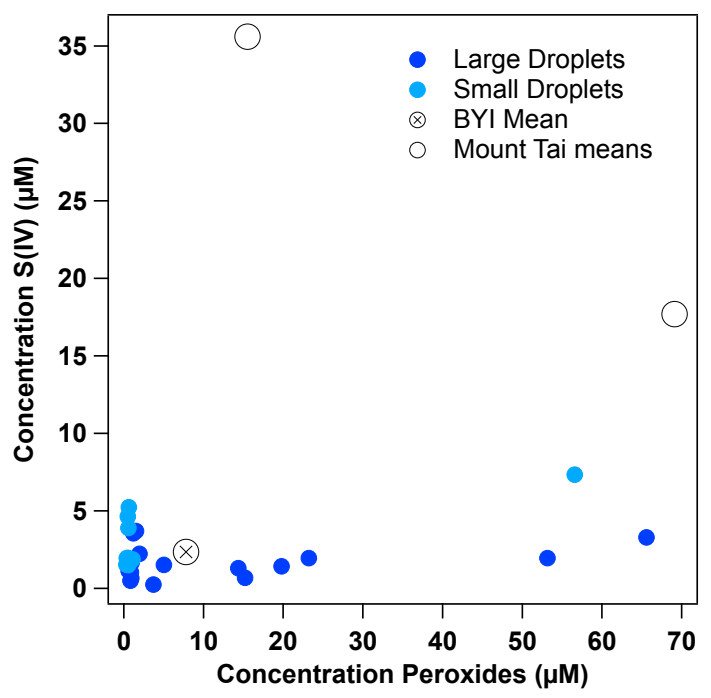

Figure 5. Droplet size-segregated concentrations of S(IV) and peroxides quantified in BYI fog samples. S(IV) concentrations were low in BYI fog as compared to those measured at Mount Tai (summer 2007 and 2008; Shen et al., 2012). For both species, $n=11$.

\subsection{Total organic carbon}

Concentrations of fog water TOC measured at BYI were 4.66-24.8 $\mathrm{m} \mathrm{CL}^{-1}$, with a mean of $17.0 \mathrm{~m} \mathrm{CL}^{-1}$, compa- rable to concentrations measured in polluted environments globally (Herckes et al., 2013). Although the mean BYI TOC was also similar to that measured in cloud water from Mount Tai during the summer of $2008\left(15.8 \mathrm{mg} \mathrm{CL}^{-1}\right)$, several samples impacted by agricultural burning were collected during the latter campaign ranging between 100 and $200 \mathrm{mg} \mathrm{CL}^{-1}$ (Shen, 2011).

\subsection{Organic acids}

The products of AAOP reactions commonly include $\mathrm{C}_{2}-\mathrm{C}_{4}$ (two to four carbon) oxo- and dicarboxylic acid molecules (Lim et al., 2010). The percent BYI fog TOC accounted for by organic acids was $36-69 \%$ (mean $52 \%$ by mole; $n=6$ ), which is at the upper end of values typical for fog samples (e.g., 16\% at Davis, CA, Herckes et al., 2002a; $18 \%$ at Angiola, CA, Ervens et al., 2003; $43 \%$ at Fresno, CA, Collett et al., 2008; and $44 \%$ at Baton Rouge, LA, and $51 \%$ at Houston, TX, Raja et al., 2008). Among the organic acids quantified, major contributions to TOC came not only from acetate and formate but also succinate, maleate and oxalate, with lesser but substantial contributions from other acids (Fig. 6).

Concentrations of low molecular mass organic acids were strongly correlated with one another (air equivalent concentrations): $r^{2}=0.83$ on average, with probability $p \leq 0.01$ of random correlation, ranging from 0.47 to $0.99(p \leq 0.001$ to 0.2 ) for $\mathrm{C}_{1}-\mathrm{C}_{6}$ mono- and diacids. The predominance of 


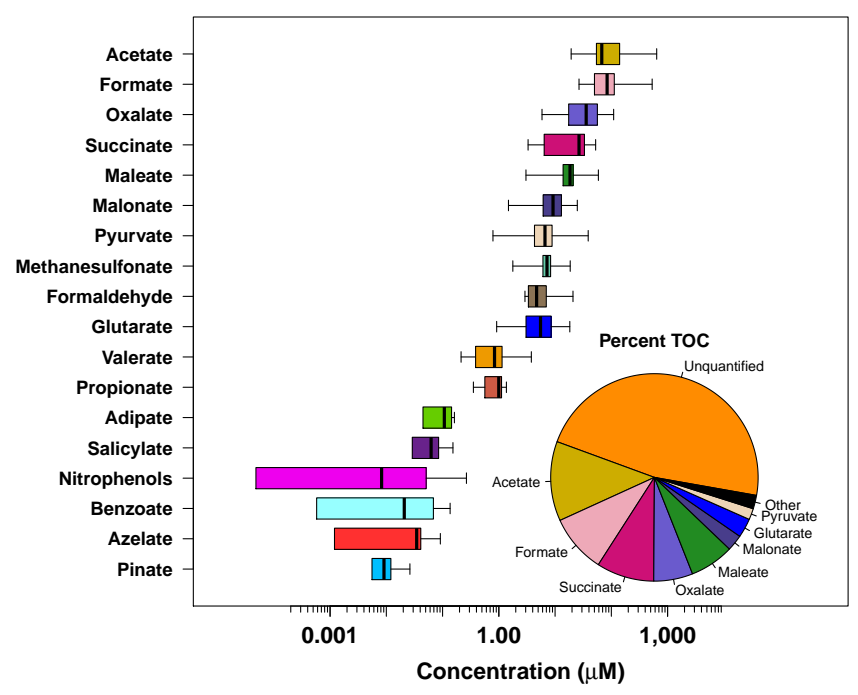

Figure 6. Concentrations of major carbonaceous components quantified in BYI fog samples. Box-and-whisker plot shows 25th and 75th percentiles with the median bar in the center, and whiskers at the min and max. Note that for $\mathrm{C}_{1}-\mathrm{C}_{5}$ organic acids, $n=11$; for formaldehyde, $n=10$; and for components with $\mathrm{C}_{6}$ or greater, $n=11$. Pie chart (inset) shows carbonaceous composition as a percentage of TOC (only those samples with results from all organic analyses included, $n=6$ ).

succinate suggests a major anthropogenic source of organic acids at BYI (Kawamura and Ikushima, 1993). While substantial contributions of oxalate to TOC suggest that AAOP reactions took place, they are not unequivocal evidence of it, since other atmospheric sources for oxalate have been documented (e.g., Kawamura and Kaplan, 1987; Yamasoe et al., 2000). The presence of MSA in the observed samples and its correlation with other measured organic acids $\left(r^{2} \leq 0.7\right.$ and $p \leq 0.02$ with all low molecular mass organic acids, $r^{2}=0.88$ and $p \leq 0.001$ with oxalate) additionally supports the occurrence of AAOP upwind of fog water collection.

\subsection{Mass spectral analysis}

Polar organic components of the fog water with $\geq \mathrm{C}_{4}$ were tentatively identified using HPLC-(-)-ESI-HR-ToFMS. These compounds were biogenic and anthropogenic in origin, including pinic acid and monoterpene-derived organosulfates, and phthalic acid (Table 2). Dicarboxylic and hydroxy dicarboxylic acids are prominent within the polar organic matter of the BYI fog samples. A van Krevelen diagram (Chen et al., 2015; Heald et al., 2010; Mazzoleni et al., 2010; Noziere et al., 2015) was used to illustrate the distribution of organic species identified within all fog water samples (CHO, CHNO, CHOS, CHNOS; Fig. 7), with the objectives of showing groupings of like species within the fog samples, and comparing the fog composition to previously analyzed atmospheric samples.
Molecules differing by specific, oxygen-containing elemental combinations can be identified in van Krevelen space by slope: i.e., addition of carbonyl $(-2 \mathrm{H},+1 \mathrm{O}$; slope $=-2)$; carboxylic acid $(-2 \mathrm{H},+2 \mathrm{O}$; slope $=-1)$; alcohol (or oxidation of an aldehyde to a carboxylic acid group; slope $=0$ ); or water (slope $=+2$ ). In BYI fog samples, families of species differing by methylene $\left(\mathrm{CH}_{2}\right)$ are visible: (1) saturated diacids $\left(\mathrm{C}_{5}-\mathrm{C}_{7}\right.$; slope $\left.=-0.5\right)$, (2) hydroxy diacids $\left(\mathrm{C}_{5}-\mathrm{C}_{7}\right.$; slope $\left.=-0.7\right)$, (3) hydroxy monounsaturated diacids $\left(\mathrm{C}_{7}-\mathrm{C}_{9}\right.$; slope $\left.=-0.8\right)$, (4) monounsaturated diacids $\left(\mathrm{C}_{4}-\mathrm{C}_{9}\right.$; slope $\left.=-1\right)$, (5) nitrophenols (dimethyl nitrophenol, methyl nitrophenol, and nitrophenol; slope $=-2.3)$, and (6) organosulfates $\left(\mathrm{C}_{9} \mathrm{H}_{16} \mathrm{O}_{7} \mathrm{~S}\right.$ through $\mathrm{C}_{6} \mathrm{H}_{10} \mathrm{O}_{7} \mathrm{~S}$; slope $=-0.3$ ). The slopes between points in these families vary because the $\mathrm{O}$ content remains constant while the $\mathrm{C}$ and $\mathrm{H}$ contents differ. A family of phthalate derivatives (7) with differing oxygen contents $\left(\mathrm{C}_{8} \mathrm{H}_{6} \mathrm{O}_{3}\right.$ through $\mathrm{C}_{8} \mathrm{H}_{6} \mathrm{O}_{5}$; slope $=0$ ) is also visible. Several CHO species were additionally identified as both biogenic and anthropogenic secondary organic species; for example, 3methyl-1,2,3-butanetricarboxylic acid (MBTCA) was tentatively identified $\left(m / z^{-} 203.058\right.$ and formula $\left.\mathrm{C}_{8} \mathrm{H}_{12} \mathrm{O}_{6}\right)$, as was diaterpenylic acid $\left(m / z^{-} 189.078 ; \mathrm{C}_{8} \mathrm{H}_{14} \mathrm{O}_{5}\right)$, which are gas-phase oxidation products of $\alpha$-pinene (Szmigielski et al., 2007; Yasmeen et al., 2010). Based on a qualitative analysis of mass spectral peak areas, westerly air masses brought the greatest quantities of anthropogenic species to BYI fog water, while the greatest biogenic species quantities were contributed by air masses from the west and east (depending on the constituent; note that only one sample with an easterly back trajectory was available; see Fig. SI-5). Mean O/C and $\mathrm{H} / \mathrm{C}$ of ambient aerosol samples (mass-normalized, from aerosol mass spectrometry; Heald et al., 2010; $\mathrm{Ng}$ et al., 2011; Chen et al., 2015) typically fall on a line within van Krevelen space at a slope of -1 and $y$ intercept of 2 for samples with fresh emissions and a slope of -0.5 for ru$\mathrm{ral} / \mathrm{remote}$ samples. Within the molecular level analysis employed here, the slopes between -1 and -0.5 appear to correspond to families of organic acids differing by a $\mathrm{CH}_{2}$ group, with differing levels of unsaturation and/or number of hydroxyl groups. The space within the van Krevelen diagram occupied by these identified families indicates they are chemically similar to aged aerosol from previous studies (Chen et al., 2015) and may be analogous to ring-opened and oxygenated species present within the fragmentation scheme of the atmospheric aging process (Kroll et al., 2009).

\subsection{Nitrophenols}

Four identified nitrophenols were quantified via HPLC(-)-ESI-HR-ToF-MS (Table SI-4 in the Supplement): 4-nitrophenol $(20.9 \pm 1.8 \mathrm{nM}$; $\max 1440 \mathrm{nM})$, 2-methyl-4nitrophenol $(3.6 \pm 0.5 \mathrm{nM}$; $\max 40 \mathrm{nM}), 2$,4-dinitrophenol $(20.2 \pm 0.1 \mathrm{nM} ; \max 70 \mathrm{nM})$. Concentrations detected in most previous fog and cloud water field studies were 
Table 2. Chemical formulae and possible structures of organic components identified via HPLC-(-)-ESI-HR-ToF-MS within BYI fog water samples. Formulae with multiple isomers (different retention times) are marked with an asterisk $\left(^{*}\right)$. Multiple plausible formulae were identified for species prefixed with "e.g.". Only species with mass spectral abundances $\geq 500$ abundance units were included.

\begin{tabular}{|c|c|c|c|c|c|}
\hline$m / z^{-}$ & Molecular formula & $\begin{array}{r}t_{\mathrm{R}} \\
(\min )\end{array}$ & $\mathrm{O} / \mathrm{C}$ & $\mathrm{H} / \mathrm{C}$ & $\begin{array}{l}\text { Possible identification } \\
\text { and references }\end{array}$ \\
\hline 85.0311 & $\mathrm{C} 4 \mathrm{H} 6 \mathrm{O} 2$ & 3.182 & 0.5 & 0.67 & Methacrylic acid \\
\hline 105.034 & & 9.32 & & & \\
\hline 113.027 & $\mathrm{C} 5 \mathrm{H} 6 \mathrm{O} 3$ & 3.67 & 0.6 & 1.2 & Oxopentenoic acid \\
\hline 117.057 & $\mathrm{C} 5 \mathrm{H} 10 \mathrm{O} 3$ & 4.54 & 0.6 & 2 & Hydroxypentanoic acid* \\
\hline 117.057 & $\mathrm{C} 5 \mathrm{H} 10 \mathrm{O} 3$ & 3.43 & 0.6 & 2 & Hydroxypentanoic acid* \\
\hline 121.031 & $\mathrm{C} 7 \mathrm{H} 6 \mathrm{O} 2$ & 9.82 & 0.29 & 0.86 & Hydroxybenzaldehyde \\
\hline 127.042 & $\mathrm{C} 6 \mathrm{H} 8 \mathrm{O} 3$ & 5.79 & 0.5 & 1.3 & Oxohexenoic acid \\
\hline 129.022 & $\mathrm{C} 5 \mathrm{H} 6 \mathrm{O} 4$ & 3.67 & 0.8 & 1.2 & Pentenedioic acid* \\
\hline 129.021 & C5H6O4 & 3.18 & 0.8 & 1.2 & Pentenedioic acid* \\
\hline 129.057 & C6H10O3 & 5.96 & 0.5 & 1.7 & Methyloxopentanoic acid* \\
\hline 129.057 & C6H10O3 & 7.00 & 0.5 & 1.7 & Methyloxopentanoic acid* \\
\hline 131.036 & C5H8O4 & 3.18 & 0.8 & 1.6 & Methylsuccinic acid \\
\hline 131.036 & $\mathrm{C} 5 \mathrm{H} 8 \mathrm{O} 4$ & 4.34 & 0.8 & 1.6 & Glutaric acid \\
\hline 131.073 & C6H12O3 & 9.82 & 0.5 & 2 & Hydroxyhexanoic acid* \\
\hline 131.073 & C6H12O3 & 7.95 & 0.5 & 2 & Hydroxyhexanoic acid* \\
\hline 137.026 & C7H6O3 & 16.17 & 0.43 & 0.86 & Salicylic acid \\
\hline 138.021 & $\mathrm{C} 6 \mathrm{H} 5 \mathrm{NO} 3$ & 13.18 & 0.5 & 0.83 & 4-Nitrophenol \\
\hline 143.036 & $\mathrm{C} 6 \mathrm{H} 8 \mathrm{O} 4$ & 3.18 & 0.67 & 1.7 & Hexenedioic acid* \\
\hline 143.037 & $\mathrm{C} 6 \mathrm{H} 8 \mathrm{O} 4$ & 6.86 & 0.67 & 1.7 & Hexenedioic acid* \\
\hline 143.073 & $\mathrm{C} 7 \mathrm{H} 12 \mathrm{O} 3$ & 11.43 & 0.43 & 1.7 & Methylpentenedioic acid \\
\hline 145.051 & C6H10O4 & 8.93 & 0.67 & 1.7 & Methylglutaric acid* \\
\hline 145.052 & $\mathrm{C} 6 \mathrm{H} 10 \mathrm{O} 4$ & 7.10 & 0.67 & 1.7 & Adipic acid \\
\hline 145.052 & C6H10O4 & 9.52 & 0.67 & 1.7 & Methylglutaric acid* \\
\hline 149.026 & $\mathrm{C} 8 \mathrm{H} 6 \mathrm{O} 3$ & 9.32 & 0.38 & 0.75 & Formylbenzoic acid \\
\hline 152.036 & $\mathrm{C} 7 \mathrm{H} 7 \mathrm{NO} 3$ & 17.85 & 0.43 & 1 & Methylnitrophenol \\
\hline 152.037 & $\mathrm{C} 7 \mathrm{H} 7 \mathrm{NO} 3$ & 19.33 & 0.43 & 1 & 2-Methyl-4-nitrophenol \\
\hline 154.016 & $\mathrm{C} 6 \mathrm{H} 5 \mathrm{NO} 4$ & 10.46 & 0.67 & 0.83 & Nitroguaiacol \\
\hline 157.052 & $\mathrm{C} 7 \mathrm{H} 10 \mathrm{O} 4$ & 6.32 & 0.57 & 1.4 & Heptenedioic acid* \\
\hline 157.053 & $\mathrm{C} 7 \mathrm{H} 10 \mathrm{O} 4$ & 5.22 & 0.57 & 1.4 & Heptenedioic acid* \\
\hline 159.068 & $\mathrm{C} 7 \mathrm{H} 12 \mathrm{O} 4$ & 10.79 & 0.57 & 1.7 & Pimelic acid \\
\hline 163.042 & С9H8O3 & 12.63 & 0.33 & 0.89 & Previously identified (Desyaterik et al., 2013) \\
\hline 165.021 & $\mathrm{C} 8 \mathrm{H} 6 \mathrm{O} 4$ & 10.13 & 0.5 & 0.75 & Phthalic acid \\
\hline 165.021 & $\mathrm{C} 8 \mathrm{H} 6 \mathrm{O} 4$ & 12.06 & 0.5 & 0.75 & Benzenedicarboxylic acid \\
\hline 166.053 & $\mathrm{C} 8 \mathrm{H} 9 \mathrm{NO} 3$ & 23.61 & 0.38 & 1.1 & Dimethylnitrophenol \\
\hline 171.067 & $\mathrm{C} 8 \mathrm{H} 12 \mathrm{O} 4$ & 8.33 & 0.5 & 1.5 & Octenedioic acid* \\
\hline 171.068 & $\mathrm{C} 8 \mathrm{H} 12 \mathrm{O} 4$ & 6.95 & 0.5 & 1.5 & Octenedioic acid* \\
\hline 171.983 & & 19.712 & & & \\
\hline 173.047 & $\mathrm{C} 7 \mathrm{H} 10 \mathrm{O} 5$ & 4.22 & 0.71 & 1.4 & Isoprene photooxidation product (Nguyen et al., 2011) \\
\hline 179.037 & $\mathrm{C} 9 \mathrm{H} 8 \mathrm{O} 4$ & 15.23 & 0.44 & 0.89 & Phthalic acid, methyl ester \\
\hline 181.016 & $\mathrm{C} 8 \mathrm{H} 6 \mathrm{O} 5$ & 5.65 & 0.63 & 0.75 & Hydroxybenzenedicarboxylic acid* \\
\hline 181.016 & $\mathrm{C} 8 \mathrm{H} 6 \mathrm{O} 5$ & 8.81 & 0.63 & 0.75 & Hydroxybenzenedicarboxylic acid* \\
\hline 181.019 & C5H10O5S & 2.82 & 1 & 2 & Previously identified (Nguyen et al., 2014a) \\
\hline
\end{tabular}

1-300 nM (Harrison et al., 2005), in the same range as identified in this study. However, the concentrations of 4-nitrophenol measured within cloud water from Mount Tai were as high as $15 \mu \mathrm{M}$ (Desyaterik et al., 2013). The lower concentrations measured at BYI versus at Mount Tai likely reflect the strong influence of aged biomass burning emissions in the Mount Tai region, and may also be a result of aqueous aging in the samples collected at
BYI, since species such as 4-nitrophenol are oxidized by - $\mathrm{OH}$ in the aqueous phase (Zhang et al., 2003). Other nitrate-containing species (tentatively identified; Table 2) included a second methyl nitrophenol isomer $\left(\mathrm{m} / \mathrm{z}^{-}\right.$152.04, $\mathrm{C}_{7} \mathrm{H}_{7} \mathrm{NO}_{3}$ ), a hydroxy nitrophenol (also called a nitrocatechol; $m / z^{-} 154.02, \mathrm{C}_{6} \mathrm{H}_{5} \mathrm{NO}_{4}$ ), a dimethyl nitrophenol $\left(m / z^{-} 166.05, \mathrm{C}_{8} \mathrm{H}_{9} \mathrm{NO}_{3}\right)$, and three other oxygenated nitrophenols $\left(m / z^{-} 228.02, \quad \mathrm{C}_{8} \mathrm{H}_{7} \mathrm{NO}_{7} ; m / z^{-} 284.05\right.$, 
Table 2. Continued.

\begin{tabular}{|c|c|c|c|c|c|}
\hline$m / z^{-}$ & Molecular formula & $\begin{array}{r}t_{\mathrm{R}} \\
(\min )\end{array}$ & $\mathrm{O} / \mathrm{C}$ & $\mathrm{H} / \mathrm{C}$ & $\begin{array}{l}\text { Possible identification } \\
\text { and references }\end{array}$ \\
\hline 182.012 & C7H5NO5 & 18.75 & 0.71 & 1 & Carboxynitrophenol \\
\hline 182.999 & $\mathrm{C} 4 \mathrm{H} 8 \mathrm{O} 6 \mathrm{~S}$ & 1.92 & 1.5 & 2 & \\
\hline 183.007 & $\mathrm{C} 6 \mathrm{H} 4 \mathrm{~N} 2 \mathrm{O} 5$ & 15.08 & 0.83 & 0.67 & 2,4-Dinitrophenol \\
\hline 185.083 & $\mathrm{C} 9 \mathrm{H} 14 \mathrm{O} 4$ & 13.54 & 0.44 & 1.6 & Pinic acid* \\
\hline 185.084 & $\mathrm{C} 9 \mathrm{H} 14 \mathrm{O} 4$ & 9.70 & 0.44 & 1.6 & Nonenedioic acid* \\
\hline 187.063 & $\mathrm{C} 8 \mathrm{H} 12 \mathrm{O} 5$ & 5.10 & 0.63 & 1.5 & $\alpha$-Pinene oxidation product (Claeys et al., 2009)* \\
\hline 187.064 & $\mathrm{C} 8 \mathrm{H} 12 \mathrm{O} 5$ & 7.76 & 0.63 & 1.5 & $\alpha$-Pinene oxidation product* \\
\hline 189.078 & $\mathrm{C} 8 \mathrm{H} 14 \mathrm{O} 5$ & 6.54 & 0.63 & 1.8 & $\begin{array}{l}\text { Diaterpenylic acid; } \\
\text { known oxidation product of } \alpha \text {-pinene (Yasmeen et al., 2010) }\end{array}$ \\
\hline 195.034 & C6H12O5S & 6.17 & 0.83 & 2 & \\
\hline 195.035 & C6H12O5S & 6.0 & 0.83 & 2 & \\
\hline 197.022 & C7H6N2O5 & 21.23 & 0.71 & 0.86 & Methyl dinitrophenol \\
\hline 201.079 & $\mathrm{C} 9 \mathrm{H} 14 \mathrm{O} 5$ & 10.74 & 0.56 & 1.6 & $\alpha$-Pinene oxidation product (Kahnt et al., 2013) \\
\hline 203.058 & $\mathrm{C} 8 \mathrm{H} 12 \mathrm{O} 6$ & 8.75 & 0.75 & 1.5 & $\begin{array}{l}\text { Methylbutanetricarboxylic acid (MBTCA); } \\
\text { gas-phase pinonic acid oxidation product (Szmigielski et al., 2007) }\end{array}$ \\
\hline 211.031 & C6H12O6S & 7.40 & 1 & 2 & \\
\hline 211.031 & C6H12O6S & 6.86 & 1 & 2 & \\
\hline 211.031 & C6H12O6S & 9.40 & 1 & 2 & \\
\hline 225.009 & C6H10O7S & 2.50 & 1.2 & 1.2 & Methylglyoxal oxidation product (Sareen et al., 2010) \\
\hline 228.021 & $\mathrm{C} 8 \mathrm{H} 7 \mathrm{NO} 7$ & 12.97 & 0.88 & 0.88 & Oxygenated nitrophenol \\
\hline 239.025 & $\mathrm{C} 7 \mathrm{H} 12 \mathrm{O} 7 \mathrm{~S}$ & 4.10 & 1 & 1.7 & 1,3,5-Trimethylbenzene oxidation product (Praplan et al., 2014) \\
\hline 239.048 & & 21.56 & 0.5 & 2 & \\
\hline 241.005 & C6H10O8S & 2.18 & 1.5 & 1.7 & \\
\hline 253.042 & $\mathrm{C} 8 \mathrm{H} 14 \mathrm{O} 7 \mathrm{~S}$ & 7.59 & 0.88 & 1.8 & Limonene oxidation product (Mazzoleni et al., 2010; Surratt et al., 2008)* \\
\hline 267.057 & $\mathrm{C} 9 \mathrm{H} 16 \mathrm{O} 7 \mathrm{~S}$ & 10.55 & 0.78 & 1.8 & Limonene oxidation product (Mazzoleni et al., 2010; Nguyen et al., 2014)* \\
\hline 267.058 & $\mathrm{C} 9 \mathrm{H} 16 \mathrm{O} 7 \mathrm{~S}$ & 10.85 & 0.78 & 1.8 & Limonene oxidation product(Mazzoleni et al., 2010; Nguyen et al., 2014)* \\
\hline 267.058 & $\mathrm{C} 9 \mathrm{H} 16 \mathrm{O} 7 \mathrm{~S}$ & 9.92 & 0.78 & 1.8 & Limonene oxidation product (Mazzoleni et al., 2010; Nguyen et al., 2014)* \\
\hline 267.058 & $\mathrm{C} 9 \mathrm{H} 16 \mathrm{O} 7 \mathrm{~S}$ & 11.00 & 0.78 & 1.8 & Limonene oxidation product (Mazzoleni et al., 2010; Nguyen et al., 2014)* \\
\hline 269.036 & C8H14O8S & 7.44 & 1 & 1.8 & \\
\hline 284.047 & C11H11NO8 & 14.96 & 0.72 & 1 & \\
\hline 294.068 & $\mathrm{C} 10 \mathrm{H} 17 \mathrm{NO} 7 \mathrm{~S}$ & 24.87 & 0.7 & 1.7 & Monoterpene oxidation product (Surratt et al., 2008)* \\
\hline 294.068 & $\mathrm{C} 10 \mathrm{H} 17 \mathrm{NO} 7 \mathrm{~S}$ & 26.71 & 0.7 & 1.7 & Monoterpene oxidation product* \\
\hline 297.060 & e.g., C17H14O3S & 8.87 & & & \\
\hline 310.063 & $\mathrm{C} 10 \mathrm{H} 17 \mathrm{NO} 8 \mathrm{~S}$ & 19.56 & 0.8 & 1.7 & Monoterpene oxidation product (Mazzoleni et al., 2010; Surratt et al., 2008)* \\
\hline 333.021 & C14H10N2O6S & 20.65 & 0.43 & 0.71 & \\
\hline 361.165 & $\mathrm{C} 15 \mathrm{H} 26 \mathrm{~N} 2 \mathrm{O} 8$ & 12.32 & 0.53 & 1.7 & \\
\hline 497.333 & C23H50N2O7S & 16.74 & 0.3 & 2.2 & \\
\hline 514.322 & $\mathrm{C} 22 \mathrm{H} 49 \mathrm{~N} 3 \mathrm{O} 8 \mathrm{~S}$ & 16.74 & 0.36 & 2.2 & \\
\hline 635.351 & e.g., $\mathrm{C} 26 \mathrm{H} 56 \mathrm{~N} 2 \mathrm{O} 13 \mathrm{~S}$ & 18.46 & & & \\
\hline
\end{tabular}

$\mathrm{C}_{11} \mathrm{H}_{11} \mathrm{NO}_{8}$; and $\left.m / z^{-361.16}, \mathrm{C}_{15} \mathrm{H}_{26} \mathrm{~N}_{2} \mathrm{O}_{8}\right)$. These nitrogen-containing organic species may have originated from biomass burning and/or wildfires in Southeast Asia and eastern Russia during the fog study period. For the three events with quantified fog nitrophenol concentrations above detection limits, large-scale fires were detected in upwind source regions (MODIS data). Levoglucosan (a biomass burning marker) concentrations measured within fog samples from BYI were below background concentrations measured in aerosol samples (Weber et al., 2007); however, those concentrations measured within the fog from 2 July were high relative to other fog samples (Fig. SI-7), and thus may have been impacted by biomass burning emissions.
Aqueous solubility of levoglucosan as well as oxidation processes may have affected the concentrations measured in BYI fog samples. Concentrations of the biomass burning marker $\mathrm{K}^{+}$were additionally above the study mean on dates when regional fires were detected (Fig. SI-6) and a correlation of $r^{2}=0.93(n=11, p \leq 0.001)$ was observed between $\mathrm{nss}^{+} \mathrm{K}^{+}$and total quantified nitrophenols as air equivalent concentrations $\left(\mathrm{nmol} \mathrm{m}^{-3}\right)$.

\subsection{Organosulfates}

Organic sulfur (CHOS) species were identified within BYI fog samples (Table 2), some of which have also been found 


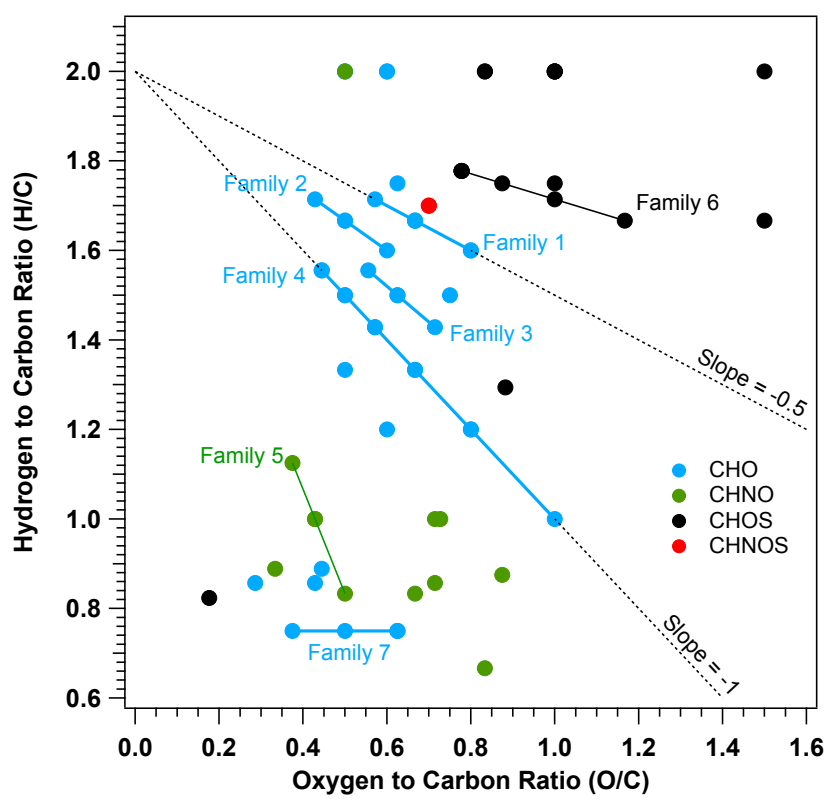

Figure 7. Polar organic compounds identified within fog samples using HPLC-(-)-ESI-HR-ToF-MS detection illustrated via a van Krevelen diagram. Colors of points distinguish compound elemental composition; solid lines show families differing by methylene groups of diacids (blue, families 1-4), nitrophenols (green, family 5), and organosulfates (black, family 6); aromatic oxygenated species differing by an $\mathrm{O}$ atom are also shown (blue, family 7). Dashed lines show slopes typical of samples in previous studies (Chen et al., 2015) of -0.5 for remote/rural (top) and -1 for urban (bottom); organic acid families fit within the space of these previously analyzed atmospheric samples.

within rainwater (samples collected in urban and rural New Jersey; Altieri et al., 2009). Most organosulfates identified were likely from oxidation and sulfonation of biogenic emissions, including $m / z^{-} 225.01,253.04$, and 267.06 corresponding to $\mathrm{C}_{6} \mathrm{H}_{10} \mathrm{O}_{7} \mathrm{~S}, \mathrm{C}_{8} \mathrm{H}_{14} \mathrm{O}_{7} \mathrm{~S}$, and $\mathrm{C}_{9} \mathrm{H}_{16} \mathrm{O}_{7} \mathrm{~S}$, respectively; however, no isoprene-derived organosulfates were detected in the BYI samples (Surratt et al., 2008). Nguyen et al. (2014) observed a compound with the formula $\mathrm{C}_{8} \mathrm{H}_{14} \mathrm{O}_{7} \mathrm{~S}$ in aerosol samples, and Surratt et al. (2008) showed that the source may have been esterification of a $d$-limonene oxidation product with $\mathrm{SO}_{4}^{-2}$. An observed compound at $m / z^{-} 239.02$ with a formula of $\mathrm{C}_{7} \mathrm{H}_{12} \mathrm{O}_{7} \mathrm{~S}$ was previously identified by Praplan et al. (2014) as an oxidation product of the anthropogenic species 1,3,5-trimethylbenzene. Several pairs of organosulfates appear to have originated from loss of a hydroxyl group: for example, $m / z^{-} 195.03$ and 211.03, corresponding to $\mathrm{C}_{6} \mathrm{H}_{12} \mathrm{O}_{5} \mathrm{~S}$ and $\mathrm{C}_{6} \mathrm{H}_{12} \mathrm{O}_{6} \mathrm{~S}$; the latter species was noted to possibly be formed from the sulfonation of a fatty acid (Surratt et al., 2008). CHONS species were also found in the fog samples from BYI, two of which were identified previously as monoterpene oxidation products (Surratt et al., 2008): $\mathrm{m} / \mathrm{z}^{-} 294.07$ with formula $\mathrm{C}_{10} \mathrm{H}_{17} \mathrm{NO}_{7} \mathrm{~S}$ and $m / z^{-} 310.06$ with formula $\mathrm{C}_{10} \mathrm{H}_{17} \mathrm{NO}_{8} \mathrm{~S}$.
A compound with the formula $\mathrm{C}_{10} \mathrm{H}_{17} \mathrm{NO}_{7} \mathrm{~S}$ was also identified within Fresno fog samples (Mazzoleni et al., 2010).

\subsection{Atmospheric aqueous organic processing}

Many features of the fog water at BYI, including the organic composition and the humid conditions encountered prior to arrival at the collection site, suggest that components in the fog were oxidized in the atmospheric aqueous phase. The oxidation may have occurred in the fogs themselves or during upwind transport of wet aerosol later scavenged by the fog. The RH upwind of fog-producing air masses as they traveled to BYI was high, with only a few time periods at $<50 \%$, and mean 65-91\% (Fig. SI-7). Only the air mass intercepted during the fog event on 30 June did not encounter RH $>80 \%$ within $72 \mathrm{~h}$ of fog formation at BYI. Mixtures of organic and inorganic components can easily take up water (growth factors $\leq 1.71$ at $85 \%$ RH for several organic acids, Wise et al., 2003 ; and $\leq 1.16$ at $85 \%$ RH for chamber-generated secondary organic aerosol, Varutbangkul et al., 2006). It is therefore likely that the aerosol LWC was sufficient to allow radical or even non-radical aqueous reactions to occur upwind of the BYI fog collection site (Lim et al., 2010, 2013). The high abundance and large diversity of organic acids, oxidized sulfur, lack of peroxides, and organosulfates identified within fog samples also support the hypothesis that AAOP reactions took place within wetted aerosol particles, in-cloud/fog during transit of the intercepted air masses to BYI, or within the fog at BYI (Lim et al., 2005; McNeill, 2015).

\subsection{Size and microphysical considerations}

Changes in LWC, species concentrations, and enrichments of species within large or small droplets can be indicative of many simultaneous microphysical processes: coalescence or condensational growth, evaporation, deposition, and collisions between droplets and interstitial particles (Degefie et al., 2015; Fahey et al., 2005; Seinfeld and Pandis, 2006). Figure 8 shows differences in large and small droplet concentrations of abundant chemical constituents in the BYI fog samples collected on the two stages of the sf-CASCC. Much higher volumes of liquid water were typically collected into the large droplet fraction $(>16 \mu \mathrm{m})$ than the small droplet fraction $(4-16 \mu \mathrm{m})$ at BYI; on average, the small fraction comprised only $10 \%$ of the total liquid water volume, indicating relatively large fog droplets made up most of the LWC. All species shown are enriched in the small droplet (4$16 \mu \mathrm{m})$ size fraction, with the exception of peroxides; similar observations have previously been reported in many clouds and fogs, especially for species typically associated with submicron aerosol, including $\mathrm{SO}_{4}^{-2}, \mathrm{NO}_{3}^{-}, \mathrm{NH}_{4}^{+}$, and TOC (Bator and Collett, 1997; Herckes et al., 2007; Munger et al., 1989). As in most of these prior observations, the $\mathrm{pH}$ in large BYI fog droplets was also typically higher than in small droplets. Differences in $\mathrm{pH}$ among cloud drops can give rise 

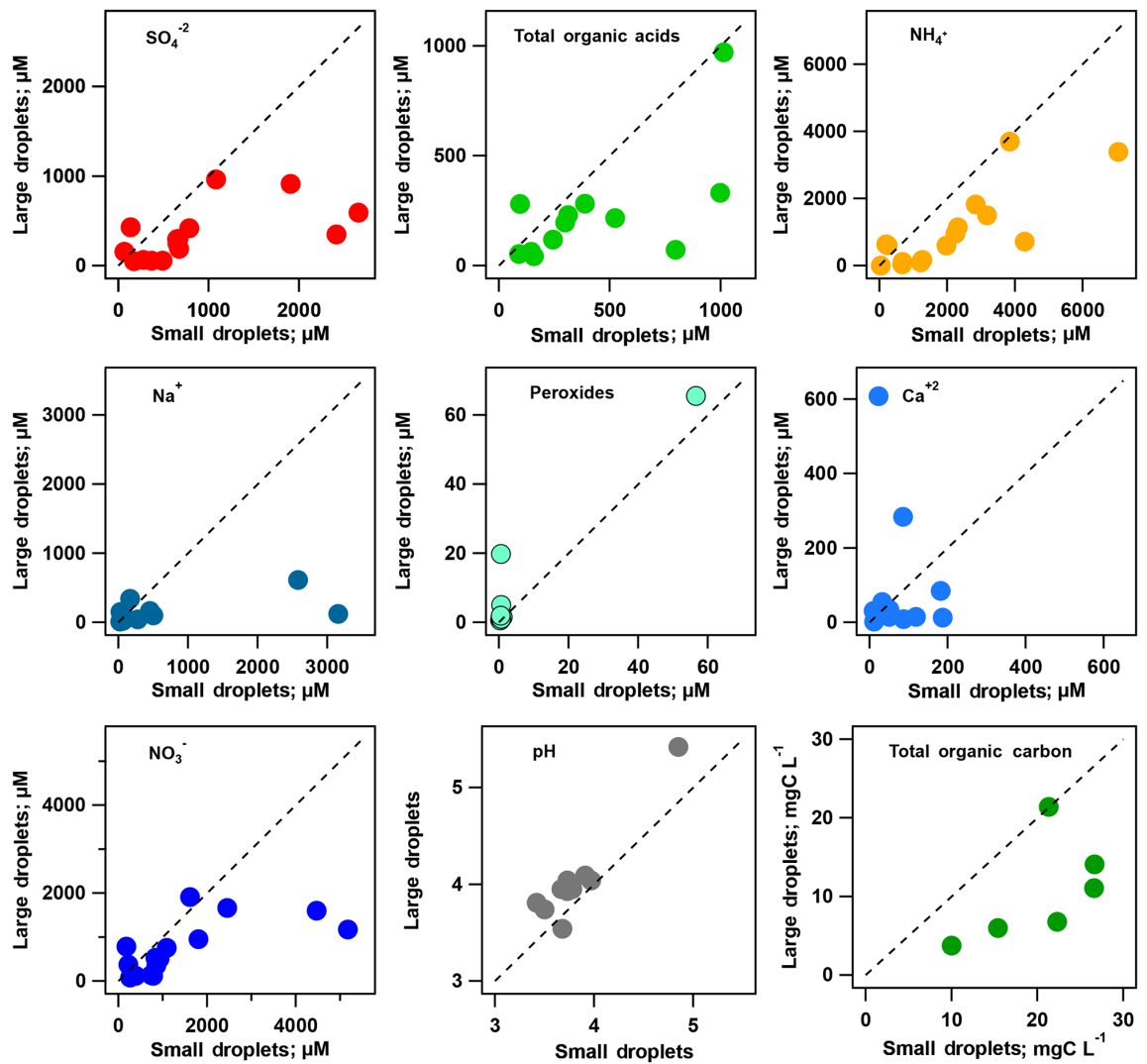

Figure 8. Scatter plots showing size distribution of major species in BYI fog water samples. All species shown, with the exception of peroxides, were enriched in small droplets.

to differences in the rates of $\mathrm{pH}$-dependent chemical reaction rates, including the aqueous oxidation of $\mathrm{S}(\mathrm{IV})$ to $\mathrm{SO}_{4}^{-2}$ by ozone or by oxygen in the presence of trace metal catalysts (Collett et al., 1994; Hegg and Larson, 1990; Rao and Collett, 1998). Enrichment of solutes in large or small fog drops can also affect rates of removal by fog drop deposition (e.g., Fahey et al., 2005; Herckes et al., 2007; Hoag et al., 1999).

\section{Conclusions}

The fogs at BYI were on average slightly acidic, and the chemical composition was dominated by $\mathrm{NH}_{4} \mathrm{NO}_{3}$ from long-range transport, with contributions from anthropogenic nss- $\mathrm{SO}_{4}^{-2}$, marine $\mathrm{NaCl}$, and a variety of organic compounds. Biomass burning activities throughout eastern Russia and Southeast Asia appear to have contributed $\mathrm{K}^{+}$and organic species, including nitrophenols, in some periods. Organosulfate species deriving from oxidation products of monoterpenes (e.g., Surratt et al., 2008; Nguyen et al., 2014) were observed, several of which have been identified in aqueous atmospheric samples in the past (Altieri et al., 2009; Mazzoleni et al., 2010). Low concentrations of S(IV), high concentrations of $\mathrm{SO}_{4}^{-2}$, and generally low concentrations of peroxides suggest that chemical components of the fog water were highly oxidized during upwind transport and/or within the local fog. Low-molecular-mass organic acids accounted for 36-69\% of TOC, a higher fraction than observed in fogs from other environments, with acetate, formate, succinate, oxalate, and maleate each contributing $>5 \%$ of TOC on average. Further analysis of the fog organic matter via HPLC(-)-ESI-HR-ToF-MS revealed homologous families of dicarboxylic acids and nitrophenols. The position within van Krevelen space occupied by identified organics matches well with the fragmentation aging regime (at high oxidation state) shown by Kroll et al. (2009).

Future studies of fog or cloud water composition in the region should include the characterization of carbonyl species which have been cited as important AAOP reactants (Ervens, 2015) and are direct oxidation precursors of organic acids. Additional studies to analyze the evolution of gaseous, particulate-, and aqueous-phase organics during fog events as well as the advancement of laboratory-simulated reactions will be essential in more fully characterizing AAOP reactions and aqSOA formation. 


\section{Data availability}

Processed data are available in the supplement to this article. Raw data are archived at the Colorado State University Atmospheric Science Department and are available on request.

\section{The Supplement related to this article is available online at doi:10.5194/acp-16-437-2016-supplement.}

Acknowledgements. The authors gratefully acknowledge the assistance and lab work of Amy Sullivan and Yury Desyaterik at Colorado State University, as well as the work of Sungwon Cho and Jungmin Yeom during the field campaign at BYI. This work was made possible through funding provided by a National Science Foundation (NSF) East Asia and Pacific Summer Institutes (EAPSI) Fellowship (1414725), which was funded in part by the National Research Foundation (NRF) of Korea (NRF2014R1A1A1007947). Research funding was also provided by NSF grant AGS-1050052; purchase of the HPLC-(-)-ESI-HR-ToF-MS system was supported through an NSF MRI grant (ATM-0521643). The authors gratefully acknowledge the employees of the Korean NIER at BYI, the laboratory of Nick Fisk in the Chemistry Department at CSU for use of the BioTek fluorescence plate reader, Hermann Gerber for assistance with the PVM-100, and the NOAA Air Resources Laboratory (ARL) for the provision of the HySPLIT transport and dispersion model (http://www.ready.noaa.gov) used in this publication.

Edited by: A. Sorooshian

\section{References}

Aiken, A. C., Decarlo, P. F., Kroll, J. H., Worsnop, D. R., Huffman, J. A., Docherty, K. S., Ulbrich, I. M., Mohr, C., Kimmel, J. R., Super, D., Sun, Y., Zhang, Q., Trimborn, A., Northway, M., Zieman, P. J., Canagaratna, M. R., Onasch, T. B., Alfarra, M. R., Prevot, A. S. H., Dommen, J., Duplissy, J., Metzger, A., Baltensperger, U., and Jimenez, J. L.: O/C and OM/OC Ratios of Primary, Secondary, and Ambient Organic Aerosols with HighResolution Time-of-Flight Aerosol Mass Spectrometry, Environ. Sci. Technol., 42, 4478-4485, doi:10.1021/es703009q, 2008.

Altieri, K. E., Turpin, B. J., and Seitzinger, S. P.: Oligomers, organosulfates, and nitrooxy organosulfates in rainwater identified by ultra-high resolution electrospray ionization FTICR mass spectrometry, Atmos. Chem. Phys., 9, 2533-2542, doi:10.5194/acp-9-2533-2009, 2009.

Andreae, M. O.: Soot carbon and excess fine potassium: Long-range transport of combustion-derived aerosols, Science, 220, 11481151, doi:10.1126/science.220.4602.1148, 1983.

Arimoto, R., Zhang, X. Y., Huebert, B. J., Kang, C. H., Savoie, D. L., Prospero, J. M., Sage, S. K., Schloesslin, C. A., Khaing, H. M., and Oh, S. N.: Chemical composition of atmospheric aerosols from Zhenbeitai, China, and Gosan, South Korea, during ACE-Asia, J. Geophys. Res., 109, D19S04, doi:10.1029/2003JD004323, 2004.
Bator, A. and Collett, J. L.: Cloud chemistry varies with drop size, J. Geophys. Res., 102, 28071-28078, doi:10.1029/97JD02306, 1997.

Benedict, K. B., Lee, T., and Collett, J. L.: Cloud water composition over the southeastern Pacific Ocean during the VOCALS regional experiment, Atmos. Environ., 46, 104-114, doi:10.1016/j.atmosenv.2011.10.029, 2012.

Bian, Q., Huang, X. H. H., and Yu, J. Z.: One-year observations of size distribution characteristics of major aerosol constituents at a coastal receptor site in Hong Kong - Part 1: Inorganic ions and oxalate, Atmos. Chem. Phys., 14, 9013-9027, doi:10.5194/acp14-9013-2014, 2014.

Blando, J. and Turpin, B.: Secondary organic aerosol formation in cloud and fog droplets: A literature evaluation of plausibility, Atmos. Environ., 34, 1623-1632, 2000.

Boris, A. J., Desyaterik, Y., and Collett, J. L.: How do components of real cloud water affect aqueous pyruvate oxidation?, Atmos. Res., 143, 95-106, doi:10.1016/j.atmosres.2014.02.004, 2014.

Borrás, E. and Tortajada-Genaro, L. A.: Secondary organic aerosol formation from the photo-oxidation of benzene, Atmos. Environ., 47, 154-163, doi:10.1016/j.atmosenv.2011.11.020, 2012.

Brinkmann, T., Hörsch, P., Sartorius, D., and Frimmel, F. H.: Photoformation of low-molecular-weight organic acids from brown water dissolved organic matter, Environ. Sci. Technol., 37, 41904198, doi:10.1021/es0263339, 2003.

Cao, G., Zhang, X., and Zheng, F.: Inventory of black carbon and organic carbon emissions from China, Atmos. Environ., 40, 65166527, doi:10.1016/j.atmosenv.2006.05.070, 2006.

Chen, Q., Heald, C. L., Jimenez, J. L., Canagaratna, M. R., He, L.y., Huang, X.-f., Campuzano-jost, P., Palm, B. B., Poulain, L., Kuwata, M., Martin, S. T., Abbatt, J. P. D., Lee, A. K. Y., and Liggio, J.: Elemental Composition of Organic Aerosol: The Gap Between Ambient and Laboratory Measurements, Geophys. Res. Lett., 42, 1-8, doi:10.1002/2015GL063693, 2015.

Cho, Y., Kim, M., and Kim, B.: Sea fog around the Korean Peninsula, J. Appl. Meteorol., 39, 2473-2479, doi:10.1175/15200450(2000)039<2473:SFATKP>2.0.CO;2, 2000.

Claeys, M., Iinuma, Y., Szmigielski, R., Surratt, J. D., Blockhuys, F., Van Alsenoy, C., Böge, O., Sierau, B., Gómez-González, Y., Vermeylen, R., Van der Veken, P., Shahgholi, M., Chan, A. W. H., Herrmann, H., Seinfeld, J. H., and Maenhaut, W.: Terpenylic acid and related compounds from the oxidation of alpha-pinene: implications for new particle formation and growth above forests., Environ. Sci. Technol., 43, 6976-82, doi:10.1021/es9007596, 2009.

Collett, J. L., Bator, A., Rao, X., and Demoz, B. B.: Acidity variations across the cloud drop size spectrum and their influence on rates of atmospheric sulfate production, Geophys. Res. Lett., 21, 2393-2396, doi:10.1029/94GL02480, 1994.

Collett, J. L., Bator, A., Sherman, D. E., Moore, K. F., Hoag, K. J., Demoz, B. B., Rao, X., and Reilly, J. E.: The chemical composition of fogs and intercepted clouds in the United States, Atmos. Res., 64, 29-40, doi:10.1016/S0169-8095(02)00077-7, 2002.

Collett, J. L., Herckes, P., Youngster, S., and Lee, T.: Processing of atmospheric organic matter by California radiation fogs, Atmos. Res., 87, 232-241, doi:10.1016/j.atmosres.2007.11.005, 2008.

Crahan, K. K., Hegg, D., Covert, D. S., and Jonsson, H.: An exploration of aqueous oxalic acid production in the 
coastal marine atmosphere, Atmos. Environ., 38, 3757-3764, doi:10.1016/j.atmosenv.2004.04.009, 2004.

Daumit, K. E., Carrasquillo, A. J., Hunter, J. F., and Kroll, J. H.: Laboratory studies of the aqueous-phase oxidation of polyols: submicron particles vs. bulk aqueous solution, Atmos. Chem. Phys., 14, 10773-10784, doi:10.5194/acp-14-10773-2014, 2014.

Decesari, S., Facchini, M., Fuzzi, S., Mcfiggans, G., Coe, H., and Bower, K.: The water-soluble organic component of sizesegregated aerosol, cloud water and wet depositions from Jeju Island during ACE-Asia, Atmos. Environ., 39, 211-222, doi:10.1016/j.atmosenv.2004.09.049, 2005.

Degefie, D., El-Madany, T.-S., Hejkal, J., Held, M., Dupont, J.-C., Haeffelin, M., and Klemm, O.: Microphysics and energy and water fluxes of various fog types at SIRTA, France, Atmos. Res., 151, 162-175, doi:10.1016/j.atmosres.2014.03.016, 2015.

Demoz, B., Collett, J., and Daube, B.: On the Caltech Active Strand Cloudwater Collectors, Atmos. Res., 41, 47-62, doi:10.1016/0169-8095(95)00044-5, 1996.

Desyaterik, Y., Sun, Y., Shen, X., Lee, T., Wang, X., Wang, T., and Collett, J. L.: Speciation of "brown" carbon in cloud water impacted by agricultural biomass burning in eastern China, J. Geophys. Res.-Atmos., 118, 7389-7399, doi:10.1002/jgrd.50561, 2013.

Edney, E. O., Driscoll, D. J., Speer, R. E., Weathers, W. S., Kleindienst, T. E., Li, W., and Smith, D. F.: Impact of aerosol liquid water on secondary organic aerosol yields of irradiated toluene/propylene/ $\mathrm{NO}_{x} /\left(\mathrm{NH}_{4}\right) 2 \mathrm{SO}_{4} /$ air mixtures, Atmos. Environ., 34, 3907-3919, 2000.

Ervens, B.: Modeling the Processing of Aerosol and Trace Gases in Clouds and Fogs, Chem. Rev., 115, 4157-4198, doi:10.1021/cr5005887, 2015.

Ervens, B., Herckes, P., Feingold, G., Lee, T., Collett, J. L., and Kreidenweis, S. M.: On the drop-size dependence of organic acid and formaldehyde concentrations in fog, J. Atmos. Chem., 46, 239-269, doi:10.1023/A:1026393805907, 2003.

Ervens, B., Turpin, B. J., and Weber, R. J.: Secondary organic aerosol formation in cloud droplets and aqueous particles (aqSOA): a review of laboratory, field and model studies, Atmos. Chem. Phys., 11, 11069-11102, doi:10.5194/acp-1111069-2011, 2011.

Ervens, B., Renard, P., Ravier, S., Clément, J.-L., and Monod, A.: Aqueous phase oligomerization of methyl vinyl ketone through photooxidation - Part 2: Development of the chemical mechanism and atmospheric implications, Atmos. Chem. Phys. Discuss., 14, 21565-21609, doi:10.5194/acpd-14-21565-2014, 2014.

Fahey, K., Pandis, S., Collett, J., and Herckes, P.: The influence of size-dependent droplet composition on pollutant processing by fogs, Atmos. Environ., 39, 4561-4574, doi:10.1016/j.atmosenv.2005.04.006, 2005.

Fu, T.-M., Jacob, D. J., Wittrock, F., Burrows, J. P., Vrekoussis, M., and Henze, D. K.: Global budgets of atmospheric glyoxal and methylglyoxal, and implications for formation of secondary organic aerosols, J. Geophys. Res., 113, D15303, doi:10.1029/2007JD009505, 2008.

Fuzzi, S., Facchini, M. C., Orsi, G., Lind, J. A., Wobrock, W., Kessell, M., Maser, R., Jaeschke, W., Enderle, K. H., Arends, B. G., Berner, A., Solly, I., Kruisz, C., Reischl, G., Pahl, S., Kaminski, U., Winkler, P., Ogren, J. A., Noone, K. J., Hall- berg, A., Fierlinger-Oberlinninger, H., Puxbaum, H., Marzorati, A., Hansson, H.-C., Wiedensohler, A., Svenningsson, I. B., Martinsson, B. G., Schell, D., and Georgii, H. W.: The Po Valley Fog Experiment 1989: An Overview, Tellus B, 44B, 448-468, doi:10.1034/j.1600-0889.1992.t01-4-00002.x, 1992.

Gerber, H.: Direct measurement of suspended particulate volume concentration and far-infrared extinction coefficient with a laser-diffraction instrument, Applied Opt., 30, 4824-31, doi:10.1364/AO.30.004824, 1991.

Heald, C. L., Jacob, D. J., Park, R. J., Russell, L. M., Huebert, B. J., Seinfeld, J. H., Liao, H., and Weber, R. J.: A large organic aerosol source in the free troposphere missing from current models, Geophys. Res. Lett., 32, 2-5, doi:10.1029/2005GL023831, 2005.

Heald, C. L., Kroll, J. H., Jimenez, J. L., Docherty, K. S., DeCarlo, P. F., Aiken, A. C., Chen, Q., Martin, S. T., and Farmer, D. K.: A simplified description of the evolution of organic aerosol composition in the atmosphere, Geophys. Res. Lett., 37, L08803, doi:10.1029/2010GL042737, 2010.

Hegg, D. A. and Larson, T. V.: The effects of microphysical parameterization on model predictions of sulfate production in clouds, Tellus, 42B, 272-284, 1990.

Herckes, P., Hannigan, M. P., Trenary, L., Lee, T., and Collett, J. L.: Organic compounds in radiation fogs in Davis (California), Atmos. Res., 64, 99-108, doi:10.1016/S0169-8095(02)00083-2, 2002a.

Herckes, P., Lee, T., Trenary, L., and Kang, G.: Organic Matter in Central California Radiation Fogs, Environ. Sci. Technol., 36, 4777-4782, 2002b.

Herckes, P., Chang, H., Lee, T., and Collett, J. L.: Air Pollution Processing by Radiation Fogs, Water Air Soil Pollut., 181, 6575, doi:10.1007/s11270-006-9276-x, 2007.

Herckes, P., Valsaraj, K. T., and Collett, J. L.: A review of observations of organic matter in fogs and clouds: Origin, processing and fate, Atmos. Res., 132-133, 434-449, doi:10.1016/j.atmosres.2013.06.005, 2013.

Hoag, K. J., Collett, J. L., and Pandis, S. N.: The influence of drop size-dependent fog chemistry on aerosol processing by San Joaquin Valley fogs, Atmos. Environ., 33, 4817-4832, doi:10.1016/S1352-2310(99)00268-X, 1999.

Kahnt, A., Behrouzi, S., Vermeylen, R., Safi Shalamzari, M., Vercauteren, J., Roekens, E., Claeys, M., and Maenhaut, W.: Oneyear study of nitro-organic compounds and their relation to wood burning in PM10 aerosol from a rural site in Belgium, Atmos. Environ., 81, 561-568, doi:10.1016/j.atmosenv.2013.09.041, 2013.

Kalberer, M., Yu, J., Cocker, D. R., Flagan, R. C., and Seinfeld, J. H.: Aerosol Formation in the Cyclohexene-Ozone System, Environ. Sci. Technol., 34, 4894-4901, doi:10.1021/es001180f, 2000.

Kamens, R. M., Zhang, H., Chen, E. H., Zhou, Y., Parikh, H. M., Wilson, R. L., Galloway, K. E., and Rosen, E. P.: Secondary organic aerosol formation from toluene in an atmospheric hydrocarbon mixture: Water and particle seed effects, Atmos. Environ., 45, 2324-2334, doi:10.1016/j.atmosenv.2010.11.007, 2011.

Kang, C.-M., Kang, B.-W., and Lee, H. S.: Source identification and trends in concentrations of gaseous and fine particulate principal species in Seoul, South Korea., J. Air Waste Manage. Assoc., 56, 911-921, doi:10.1080/10473289.2006.10464506, 2006. 
Kawamura, K. and Ikushima, K.: Seasonal changes in the distribution of dicarboxylic acids in the urban atmosphere, Environ. Sci. Technol., 27, 2227-2235, doi:10.1021/es00047a033, 1993.

Kawamura, K. and Kaplan, I.: Motor exhaust emissions as a primary source for dicarboxylic acids in Los Angeles ambient air, Environ. Sci. Technol., 21, 105-110, doi:10.1021/es00155a014, 1987.

Kawamura, K., Kobayashi, M., Tsubonuma, N., Mochida, M., Watanabe, T., and Lee, M.: Organic and inorganic compositions of marine aerosols from East Asia: Seasonal variations of watersoluble dicarboxylic acids, major ions, total carbon and nitrogen, and stable $\mathrm{C}$ and $\mathrm{N}$ isotopic composition, in: Geochemical Investigations in Earth and Space Science: A Tribute to Isaac R. Kaplan, The Geochemical Society, Amsterdam, The Netherlands, first edn., 243-265, 2004.

Kim, J. H., Yum, S. S., Shim, S., Yoon, S.-C., Hudson, J. G., Park, J., and Lee, S.-J.: On aerosol hygroscopicity, cloud condensation nuclei $(\mathrm{CCN})$ spectra and critical supersaturation measured at two remote islands of Korea between 2006 and 2009, Atmos. Chem. Phys., 11, 12627-12645, doi:10.5194/acp-1112627-2011, 2011.

Kim, M.-G., Lee, B.-K., and Kim, H.-J.: Cloud/Fog Water Chemistry at a High Elevation Site in South Korea, J. Atmos. Chem., 55, 13-29, doi:10.1007/s10874-005-9004-8, 2006.

Kleindienst, T. E., Smith, D. F., Li, W., Edney, E. O., Driscoll, D. J., Speer, R. E., and Weathers, W. S.: Secondary organic aerosol formation from the oxidation of aromatic hydrocarbons in the presence of dry submicron ammonium sulfate aerosol, Atmos. Environ., 33, 3669-3681, doi:10.1016/S1352-2310(99)00121-1, 1999.

Kroll, J. H., Smith, J. D., Dung, L. C., Kessler, S. H., Worsnop, D. R., and Wilson, K. R.: Measurement of fragmentation and functionalization pathways in the heterogeneous oxidation of oxidized organic aerosol, Phys. Chem. Chem. Phys., 11, 80058014, doi:10.1039/b916865f, 2009.

Kukui, A., Borissenko, D., Laverdet, G., and Le Bras, G.: Gas-phase reactions of $\mathrm{OH}$ radicals with dimethyl sulfoxide and methane sulfinic acid using turbulent flow reactor and chemical ionization mass spectrometry, J. Phys. Chem. A, 107, 5732-5742, doi:10.1021/jp0276911, 2003.

Lauer, A., Eyring, V., Hendricks, J., Jöckel, P., and Lohmann, U.: Global model simulations of the impact of ocean-going ships on aerosols, clouds, and the radiation budget, Atmos. Chem. Phys. Discuss., 7, 9419-9464, doi:10.5194/acpd-7-9419-2007, 2007.

Lee, T.: Characterizing ionic components of aerosol in rural environments: temporal variability, size distributions, and the form of particle nitrate, Ph.D. thesis, Colorado State University, 4-7, 117-135, 2007.

Lee, T., Sullivan, A. P., Mack, L., Jimenez, J. L., Kreidenweis, S. M., Onasch, T. B., Worsnop, D. R., Malm, W., Wold, C. E., Hao, W. M., and Collett, J. L.: Chemical Smoke Marker Emissions During Flaming and Smoldering Phases of Laboratory Open Burning of Wildland Fuels, Aerosol Sci. Technol., 44, iv, doi:10.1080/02786826.2010.499884, 2010.

Lee, T. T., Choi, J. J., Lee, G., Ahn, J. J. Y., Park, J. S., Atwood, S. A., Schurman, M., Choi, Y., Chung, Y., Collett, J. L., Choi, J. J., Ahn, J. J. Y., Park, J. S., Atwood, S. A., Schurman, M., Chung, Y., and Collett, J. L.: Characterization of Aerosol Composition, Concentrations, and Sources at Baengnyeong Island,
Korea using an Aerosol Mass Spectrometer, Atmos. Environ., 120, 297-306, 2015.

Lelieveld, J. and Crutzen, P.: The role of clouds in tropospheric photochemistry, J. Atmos. Chem., 12, 229-267, doi:10.1007/BF00048075, 1991.

Li, P., Li, X., Yang, C., Wang, X., Chen, J., and Collett, J. L.: Fog water chemistry in Shanghai, Atmos. Environ., 45, 4034-4041, doi:10.1016/j.atmosenv.2011.04.036, 2011a.

Li, W. J., Zhang, D. Z., Shao, L. Y., Zhou, S. Z., and Wang, W. $\mathrm{X}$.: Individual particle analysis of aerosols collected under haze and non-haze conditions at a high-elevation mountain site in the North China plain, Atmos. Chem. Phys., 11, 11733-11744, doi:10.5194/acp-11-11733-2011, 2011 b.

Lim, H.-J., Carlton, A. G., and Turpin, B. J.: Isoprene Forms Secondary Organic Aerosol through Cloud Processing: Model Simulations, Environ. Sci. Technol., 39, 4441-4446, doi:10.1021/es048039h, 2005.

Lim, Y. B., Tan, Y., Perri, M. J., Seitzinger, S. P., and Turpin, B. J.: Aqueous chemistry and its role in secondary organic aerosol (SOA) formation, Atmos. Chem. Phys., 10, 1052110539, doi:10.5194/acp-10-10521-2010, 2010.

Lim, Y. B., Tan, Y., and Turpin, B. J.: Chemical insights, explicit chemistry, and yields of secondary organic aerosol from $\mathrm{OH}$ radical oxidation of methylglyoxal and glyoxal in the aqueous phase, Atmos. Chem. Phys., 13, 8651-8667, doi:10.5194/acp-13-86512013, 2013.

Lin, G., Sillman, S., Penner, J. E., and Ito, A.: Global modeling of SOA: the use of different mechanisms for aqueous-phase formation, Atmos. Chem. Phys., 14, 5451-5475, doi:10.5194/acp-145451-2014, 2014.

Liu, Y., Monod, A., Tritscher, T., Praplan, A. P., DeCarlo, P. F., Temime-Roussel, B., Quivet, E., Marchand, N., Dommen, J., and Baltensperger, U.: Aqueous phase processing of secondary organic aerosol from isoprene photooxidation, Atmos. Chem. Phys., 12, 5879-5895, doi:10.5194/acp-12-5879-2012, 2012.

Mattigod, S., Rai, D., Eary, L., and Ainsworth, C.: Geochemical factors controlling the mobilisation of inorganic constituents from fossil fuel combustion residues: I, Review of the major elements, J. Environ. Qual., 19, 188-201, 1990.

Mazzoleni, L. R., Ehrmann, B. M., Shen, X., Marshall, A. G., and Collett, J. L.: Water-soluble atmospheric organic matter in fog: Exact masses and chemical formula identification by ultrahigh-resolution fourier transform ion cyclotron resonance mass spectrometry, Environ. Sci. Technol., 44, 3690-3697, doi:10.1021/es903409k, 2010.

McCulloch, A., Aucott, M. L., Benkovitz, C. M., Graedel, T. E., Kleiman, G., Midgley, P. M., and Li, Y.-F.: Global emissions of hydrogen chloride and chloromethane from coal combustion, incineration and industrial activities: Reactive Chlorine Emissions Inventory, J. Geophys. Res., 104, 8391-8403, doi:10.1029/1999JD900025, 1999.

McNeill, V. F.: Aqueous organic chemistry in the atmosphere: Sources and chemical processing of organic aerosols, Environ Sci. Technol., 49, 1237-1244, doi:10.1021/es5043707, 2015.

Moore, K. F., Sherman, D. E., Reilly, J. E., and Collett, J. L.: Drop size-dependent chemical composition in clouds and fogs. Part I. Observations, Atmos. Environ., 38, 1389-1402, doi:10.1016/j.atmosenv.2003.12.013, 2004a. 
Moore, K. F., Sherman, D. E., Reilly, J. E., Hannigan, M. P., Lee, T., and Collett, J. L.: Drop size-dependent chemical composition of clouds and fogs. Part II: Relevance to interpreting the aerosol/trace gas/fog system, Atmos. Environ., 38, 1403-1415, doi:10.1016/j.atmosenv.2003.12.014, 2004b.

Mouri, H. and Okada, K.: Shattering and modification of sea-salt particles in the marine atmosphere, Geophys. Res. Lett., 20, 4952, doi:10.2467/mripapers.57.47, 1993.

Munger, J., Collett, J., Daube, B., and Hoffmann, M.: Carboxylic acids and carbonyl compounds in southern California clouds and fogs, Tellus B, 41B, 230-242, doi:10.1111/j.16000889.1989.tb00303.x, 1989.

Narukawa, M. and Kawamura, K.: Distribution of dicarboxylic acids and carbon isotopic compositions in aerosols from 1997 Indonesian forest fires, Geophys. Res. Lett., 26, 3101-3104, doi:10.1029/1999GL010810, 1999.

Ng, N. L., Canagaratna, M. R., Jimenez, J. L., Chhabra, P. S., Seinfeld, J. H., and Worsnop, D. R.: Changes in organic aerosol composition with aging inferred from aerosol mass spectra, Atmos. Chem. Phys., 11, 6465-6474, doi:10.5194/acp-11-64652011, 2011.

Nguyen, Q. T., Christensen, M. K., Cozzi, F., Zare, A., Hansen, A. M. K., Kristensen, K., Tulinius, T. E., Madsen, H. H., Christensen, J. H., Brandt, J., Massling, A., Nøjgaard, J. K., and Glasius, M.: Understanding the anthropogenic influence on formation of biogenic secondary organic aerosols in Denmark via analysis of organosulfates and related oxidation products, Atmos. Chem. Phys., 14, 8961-8981, doi:10.5194/acp-14-8961-2014, 2014.

Noziere, B., Kalberer, M., Claeys, M., Allan, J., Anna, B. D., Decesari, S., Finessi, E., Glasius, M., Grgic, I., Hamilton, J. F., Ho, T., Iinuma, Y., Jaoui, M., Kahnt, A., Kampf, C. J., Kourtchev, I., Maenhaut, W., Marsden, N., Saarikoski, S., Schnelle-kreis, J., Surratt, J. D., Szidat, S., Szmigielski, R., and Wisthaler, A.: The molecular identification of organic compounds in the atmosphere: State of the art and challenges, Chem. Rev., 115, 39193983, doi:10.1021/cr5003485, 2015.

Pandis, S. N., Seinfeld, J. H., and Pilinis, C.: The smog-fog-smog cycle and acid deposition, J. Geophys. Res., 95, 18489-18500, doi:10.1029/JD095iD11p18489, 1990.

Prabhakar, G., Ervens, B., Wang, Z., Maudlin, L., Coggon, M., Jonsson, H., Seinfeld, J., and Sorooshian, A.: Sources of nitrate in stratocumulus cloud water: Airborne measurements during the 2011 E-PEACE and 2013 NiCE studies, Atmos. Environ., 97, 166-173, doi:10.1016/j.atmosenv.2014.08.019, 2014.

Praplan, A. P., Hegyi-Gaeggeler, K., Barmet, P., Pfaffenberger, L., Dommen, J., and Baltensperger, U.: Online measurements of water-soluble organic acids in the gas and aerosol phase from the photooxidation of 1,3,5-trimethylbenzene, Atmos. Chem. Phys., 14, 8665-8677, doi:10.5194/acp-14-8665-2014, 2014.

Radojevic, M. and Bashkin, V. N.: Practical Environmental Analysis, The Royal Society of Chemistry, Cambridge, UK, 44-73, 2006.

Raja, S., Raghunathan, R., Yu, X.-Y., Lee, T., Chen, J., Kommalapati, R. R., Murugesan, K., Shen, X., Qingzhong, Y., Valsaraj, K. T., and Collett, J. L.: Fog chemistry in the TexasLouisiana Gulf Coast corridor, Atmos. Environ., 42, 2048-2061, doi:10.1016/j.atmosenv.2007.12.004, 2008.
Rao, X. and Collett, J. L.: Behavior of S(IV) and formaldehyde in a chemically heterogeneous cloud, Environ. Sci. Technol., 29, 1023-1031, doi:10.1021/es00004a024, 1995.

Rao, X. and Collett, J. L.: The drop size-dependence of iron and manganese concentrations in clouds and fogs: Implications for sulfate production, J. Atmos. Chem., 30, 273-289, doi:10.1023/A:1006044614291, 1998.

Reilly, J. E., Rattigan, O. V., Moore, K. F., Judd, C., Eli Sherman, D., Dutkiewicz, V. a., Kreidenweis, S. M., Husain, L., and Collett, J. L.: Drop size-dependent S(IV) oxidation in chemically heterogeneous radiation fogs, Atmos. Environ., 35, 5717-5728, doi:10.1016/S1352-2310(01)00373-9, 2001.

Sareen, N., Schwier, A. N., Shapiro, E. L., Mitroo, D., and McNeill, V. F.: Secondary organic material formed by methylglyoxal in aqueous aerosol mimics, Atmos. Chem. Phys., 10, 997-1016, doi:10.5194/acp-10-997-2010, 2010.

Scaduto, R. C. J.: Oxidation of DMSO and methanesulfinic acid by the hydroxyl radical, Free Radical Biology \& Medicine, 18, 271-277, doi:10.1016/0891-5849(94)E0139-A, 1995.

Seinfeld, J. H. and Pandis, S. N.: Atmospheric Chemistry and Physics: From Air Pollution to Climate Change, vol. 2nd, John Wiley \& Sons, Inc., Hoboken, New Jersey, 267-270, 964-965, 2006.

Shen, X.: Aqueous Phase Sulfate Production in Clouds at Mt. Tai in Eastern China, Ph.D. thesis, Colorado State University, 53-55, 2011.

Shen, X., Lee, T., Guo, J., Wang, X., Li, P., Xu, P., Wang, Y., Ren, Y., Wang, W., Wang, T., Li, Y., Carn, S. A., and Collett, J. L.: Aqueous phase sulfate production in clouds in eastern China, Atmos. Environ., 62, 502-511, doi:10.1016/j.atmosenv.2012.07.079, 2012.

Sorooshian, A., Varutbangkul, V., Brechtel, F. J., Ervens, B., Feingold, G., Bahreini, R., Murphy, S. M., Holloway, J. S., Atlas, E. L., Buzorius, G., Jonsson, H., Flagan, R. C., and Seinfeld, J. H.: Oxalic acid in clear and cloudy atmospheres: Analysis of data from International Consortium for Atmospheric Research on Transport and Transformation 2004, J. Geophys. Res. 111, D23S45, doi:10.1029/2005JD006880, 2006.

Sorooshian, A., Wang, Z., Coggon, M. M., Jonsson, H. H., and Ervens, B.: Observations of Sharp Oxalate Reductions in Stratocumulus Clouds at Variable Altitudes: Organic Acid and Metal Measurements During the 2011 E-PEACE Campaign, Environ. Sci. Technol., 47, 7747-7756, 2013.

Straub, D. J., Lee, T., and Collett, J. L.: Chemical composition of marine stratocumulus clouds over the eastern Pacific Ocean, J. Geophys. Res., 112, D04307, doi:10.1029/2006JD007439, 2007.

Streets, D. G., Guttikunda, S. K., and Carmichael, G. R.: The growing contribution of sulfur emissions from ships in Asian waters, 1988-1995, Atmos. Environ., 34, 4425-4439, doi:10.1016/S1352-2310(00)00175-8, 2000.

Sullivan, A. P., Holden, A. S., Patterson, L. A., McMeeking, G. R., Kreidenweis, S. M., Malm, W. C., Hao, W. M., Wold, C. E., and Collett, J. L.: A method for smoke marker measurements and its potential application for determining the contribution of biomass burning from wildfires and prescribed fires to ambient PM 2.5 organic carbon, J. Geophys. Res., 113, D22302, doi:10.1029/2008JD010216, 2008.

Surratt, J. D., Gómez-González, Y., Chan, A. W. H., Vermeylen, R., Shahgholi, M., Kleindienst, T. E., Edney, E. O., Offenberg, J. H., 
Lewandowski, M., Jaoui, M., Maenhaut, W., Claeys, M., Flagan, R. C., and Seinfeld, J. H.: Organosulfate formation in biogenic secondary organic aerosol, J. Phys. Chem. A, 112, 834578, doi:10.1021/jp802310p, 2008.

Szmigielski, R., Surratt, J. D., Gómez-González, Y., van der Veken, P., Kourtchev, I., Vermeylen, R., Blockhuys, F., Jaoui, M., Kleindienst, T. E., Lewandowski, M., Offenberg, J. H., Edney, E. O., Seinfeld, J. H., Maenhaut, W., and Claeys, M.: 3-methyl1,2,3-butanetricarboxylic acid: An atmospheric tracer for terpene secondary organic aerosol, Geophys. Res. Lett., 34, 2-7, doi:10.1029/2007GL031338, 2007.

Varutbangkul, V., Brechtel, F. J., Bahreini, R., Ng, N. L., Keywood, M. D., Kroll, J. H., Flagan, R. C., Seinfeld, J. H., Lee, A., and Goldstein, A. H.: Hygroscopicity of secondary organic aerosols formed by oxidation of cycloalkenes, monoterpenes, sesquiterpenes, and related compounds, Atmos. Chem. Phys., 6, 23672388, doi:10.5194/acp-6-2367-2006, 2006.

Wang, B., O’Brien, R. E., Kelly, S. T., Shilling, J. E., Moffet, R. C., Gilles, M. K., and Laskin, A.: Reactivity of Liquid and Semisolid Secondary Organic Carbon with Chloride and Nitrate in Atmospheric Aerosols, J. Phys. Chem. A, 119, 4498-4508, doi:10.1021/jp510336q, 2015.

Wang, Y., Guo, J., Wang, T., Ding, A., Gao, J., Zhou, Y., Collett, J. L., and Wang, W.: Influence of regional pollution and sandstorms on the chemical composition of cloud/fog at the summit of Mt. Taishan in northern China, Atmos. Res., 99, 434-442, doi:10.1016/j.atmosres.2010.11.010, 2011.

Weber, R. J., Sullivan, A. P., Peltier, R. E., Russell, A., Yan, B., Zheng, M., de Gouw, J., Warneke, C., Brock, C., Holloway, J. S., Atlas, E. L., and Edgerton, E.: A study of secondary organic aerosol formation in the anthropogenic-influenced southeastern United States, J. Geophys. Res.-Atmos., 112, D11032, doi:10.1029/2007JD008408, 2007.

Wise, M. E., Surratt, J. D., Curtis, D. B., Shilling, J. E., and Tolbert, M. A.: Hygroscopic growth of ammonium sulfate/dicarboxylic acids, J. Geophys. Res., 108, 4368-4376, doi:10.1029/2003JD003775, 2003.

Wonaschuetz, A., Sorooshian, A., Ervens, B., Chuang, P. Y., Feingold, G., Murphy, S. M., de Gouw, J., Warneke, C., and Jonsson, H. H.: Aerosol and gas re-distribution by shallow cumulus clouds: An investigation using airborne measurements, J. Geophys. Res., 117, D17202, doi:10.1029/2012JD018089, 2012.

Yamasoe, M., Artaxo, P., Miguel, A., and Allen, A.: Chemical composition of aerosol particles from direct emissions of vegetation fires in the Amazon Basin: water-soluble species and trace elements, Atmos. Environ., 34, 1641-1653, doi:10.1016/S13522310(99)00329-5, 2000.
Yang, G.-P., Zhang, H.-H., Su, L.-P., and Zhou, L.-M.: Biogenic emission of dimethylsulfide (DMS) from the North Yellow Sea, China and its contribution to sulfate in aerosol during summer, Atmos. Environ., 43, 2196-2203, doi:10.1016/j.atmosenv.2009.01.011, 2009.

Yasmeen, F., Vermeylen, R., Szmigielski, R., Iinuma, Y., Böge, O., Herrmann, H., Maenhaut, W., and Claeys, M.: Terpenylic acid and related compounds: precursors for dimers in secondary organic aerosol from the ozonolysis of $\alpha$ - and $\beta$-pinene, Atmos. Chem. Phys., 10, 9383-9392, doi:10.5194/acp-10-9383-2010, 2010.

Yoo, J.-M., Jeong, M.-J., Hur, Y. M., and Shin, D.-B.: Improved fog detection from satellite in the presence of clouds, Asia-Pac. J. Atmos. Sci., 46, 29-40, doi:10.1007/s13143-010-0004-5, 2010.

Yu, J. Z., Huang, X.-F., Xu, J., and Hu, M.: When aerosol sulfate goes up, so does oxalate: implication for the formation mechanisms of oxalate, Environ. Sci. Technol., 39, 128-133, doi:10.1021/es049559f, 2005.

Zhang, Q., Worsnop, D. R., Canagaratna, M. R., and Jimenez, J. L.: Hydrocarbon-like and oxygenated organic aerosols in Pittsburgh: insights into sources and processes of organic aerosols, Atmos. Chem. Phys., 5, 3289-3311, doi:10.5194/acp-5-32892005, 2005.

Zhang, S.-P., Xie, S.-P., Liu, Q.-Y., Yang, Y.-Q., Wang, X.G., and Ren, Z.-P.: Seasonal Variations of Yellow Sea Fog: Observations and Mechanisms, J. Climate, 22, 6758-6772, doi:10.1175/2009JCLI2806.1, 2009.

Zhang, W., Xiao, X., An, T., and Song, Z.: Kinetics, degradation pathway and reaction mechanism of advanced oxidation of 4 nitrophenol in water by a UV/H2O2 process, J. Chem. Technol. Biotechnol., 794, 788-794, doi:10.1002/jctb.864, 2003.

Zhang, X., Arimoto, R., An, Z., Chen, T., Zhang, G., Zhu, G., and Wang, X.: Atmospheric trace elements over source regions for Chinese dust: concentrations, sources and atmospheric deposition on the Loess plateau, Atmos. Environ. A-Gen., 27, 20512067, doi:10.1016/0960-1686(93)90277-6, 1993.

Zheng, M., Salmon, L. G., Schauer, J. J., Zeng, L., Kiang, C. S., Zhang, Y., and Cass, G. R.: Seasonal trends in PM2.5 source contributions in Beijing, China, Atmos. Environ., 39, 3967-3976, doi:10.1016/j.atmosenv.2005.03.036, 2005.

Zuo, Y. and Hoigné, J.: Photochemical decomposition of oxalic, glyoxalic and pyruvic acid catalysed by iron in atmospheric waters, Atmos. Environ., 2, 1231-1239, doi:10.1016/13522310(94)90270-4, 1994. 